\title{
Social Organization in the
}

\section{Red Jungle Fowl (Gallus gallus subsp.)}

By

EDWIN M. BANKS

A DISSERTATION PRESENTED TO THE GRADUATE COUNCIL OF THE UNIVERSITY OF FLORIDA

IN PARTIAL FULFILMENT OF THE REQUIREMENTS FOR THE DEGREE OF DOCTOR OF PHILOSOPHY

UNIVERSITY OF FLORIDA

June, 1955 
LIST OF TABLES .................... Page

LIST OF ILLUSTRATIONS. . . . . . . . . . V11

INTRODUCTION .......................... I

METHODS. . . . . . . . . . . . 5

OBSERVATIONS ............................. 12

SOCIAL HIERARCHY IN HEN FLOCKS. . . . . . 12

Flock 10A. . . . . . . . . . 12

Flock lOB. . . . . . . 16

Flock 23A. . . . . . . . . . . . 20

Flock 23B. . . . . . . . . . . 22

Relative Social Status of
Hens Together in Two Flocks. . . . . . . 24

The Effect of Home Territory

on Social status ............ 27

SOCIAL ORGANIZATION IN JUNGLE FOWL COCKS. ... 30

Flock 3............. . . 30

Flock 24 A. . . . . . . : 37

Flock 24B. ................... 41

SOCIAL ORGANIZATION IN WHITE LFGHORN COCKS. .48

SOCIAL ORGANIZATION IN HETEROSEXUAL FLOCKS OF

RED JUNGLE FOWL ............ 55

Flock 18 ............ . . . 55

Flock $25 . . .0 .0 .0 .059$

Flock 23C..................... 62

Flock 24C. 66

Male Kat Ing Behavior . . . . : : : 70

Female Mating Behavior ....... 81

Summary of Soclal Organization and

Mating Behavior in Heterosexual Flocks ... 85 
TABLE OF CONTENTS -- Continued

STAGED INITIAL ENCOUNTERS BETWEEN HENS..... Page 87 TERRITORIALITY. . . . . . . . . 89

Test I................ 90

Test 2...................... 90

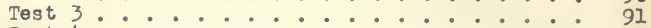

Test $4: \therefore: \therefore 2$

DISCUSSION ...................... 94

SUMARY. . . . . . . . . . . . . 113

APPENDIX . . . . . . . . . . . 117

LITERATURE CITED . . . . . . . . . . . 118

BIOGRAPHICAL SKETCH. . . . . . . . . . 122 


\section{LIST OF TABLES}

Table

1. Aggressive Interactions in Flock 10A:

Number of Observed Pecks. . . . . . . . 14

2. Aggressive Interactions in Flock 10A:

Number of Observed Threats. . . . . . 15

3. Aggressive Interactions in Flock 10B:

Number of Observed Pecks. . . . . . . . 17

4. Aggressive Interactions in Flock 1OB:

Number of Observed Threats. . . . . . . 17

5. Aggressive Interactions in Flock 23A:

Number of Observed Pecks. . . . . . . 20

6. Aggressive Interactions in Flock 23A:

Number of Observed Threats. . . . . . . 21

7. Aggressive Interactions in Flock 23B:

Number of Observed Pecks. . . . . . . 23

8. Agrressive Interactions in Flock 23B:

Number of Observed Threats. . . . . . 23

9. Relative Dominance-Subordinance Positions

of Hens Together in Two Flocks. . . . . . 25

10. Soclal Status of Hens Whlch Were Members

of Two Flocks.............. 26

11. Flock Reorjanlzation Scheme . . . . . . 27

12. Azgressive Interactions in Flock $3:$

Number of Observed Pecks.. . . . . . 32

13. Azgressive Interactions in Flock 3:

Number of Observed Threats. . . . . . 34

14. Recurrent Reversals in Dominance Recorded in Flock 3............ 35 


\section{LIST OF TABLES -- Continued}

Table

Page

15. Azgressive Interactions in Flock 3: Number of Observed Waltzes. . . . . . . .

16. Azgressive Interactions in Flock 24A: Number of Observed Pecks. . . . . . . 40

17. Azgressive Interactions in Flock 24A: Number of Observed Threats......... 40

18. Aggressive Interactions in Flock 24B: Number of Observed Pecks. . . . . . . 42

19. Agzressive Interactions in Flock 24B: Number of Observed Threats. . . . . . 44

20. Reversals in Dominance in Flock 24B ..... 44

21. Aggress1ve Interactions in Flock 2lA: Number of Observed Pecks. . . . . . . 50

22. Agzressive Interactions in Flock 21A: Number of Observed Threats. . . . . . 51

23. Agsressive Interactions in Flock 218: Number of Observed Pecks...........

24. Azgressive Interactions in Flock 21B: Number of Observed Threats. . . . . . . .

25. Azgress1ve Interactions in Flock 2lC: Number of Observed Pecks. . . . . . . . .

26. Azgressive Interactions in Flock $21 \mathrm{C}$ : Number of Observed Threats. . . . . . . .

27. Aggressive Interactions in Flock 18:

Number of Observed Pecks............

28. Agsressive Interactions in Flock 18:

Number of Observed Threats. . . . . . . .

29. Aggress1ve Interactions in Flock 25: Number of Observed Pecks.

30. Aggressive Interactions in Flock 25: Number of Observed Threats. 


\section{LIST OF TABLES -- Continued}

Table

Page

31. Aggressive Interactions in Flock 23C:

Number of Observed Pecks............

32. Agsressive Interactions in Flock 23C:

Number of Observed Threats. . . . . . . 65

33. Aggressive Interactions in Flock $24 \mathrm{C}$ :

Number of Observed Pecks. . . . . . . 68

34. Aggressive Interactions in Flock 24C:

Number of Observed Threats. . . . . . .

35. Observed Mating Behavior of Males in

Heterosexual Flocks... . . . . . . 72

36. Correlation Between Rank and Display of

Mating Behavior in Males... . . . . . 75

37. Test of Male Matinz Behavior: Number of

Mating Displays When All Cocks Are Present. .

38. Test of Male Mating Behavior: Number of Mat1ng Displays in the Absence and Presence of 21 . .

39. Test of Male Mating Behavior: Number of Mating Displays in the Absence and Presence of 21 and 97................ 80

40. Test of Male Mat1ng Behavior after Deposition of 21............... 


\section{LIST OF ILLUSTRATIONS}

Figure

Page

1. Soclograms of Hen Flocks. . . . . . . . 13

2. Soclograms of Male Flock 3. . . . . . . 33

3. Soclograms of Male Flock 24A. . . . . . . 39

4. Soclozrams of Male Flock 24B. . . . . . 43

5. Sociograms of thite Leghom Male Flocks

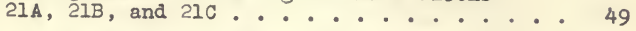

6. Soclozrams of Heterosexual Flock 18 . . . 56

7. Soclograms of Heterosexual Flock $25 . . .50$

8. Soclograms of Heterosexual Flock 23C. .... 63

9. Sociozrams of Heterosexual Flock $24 \mathrm{C}$. . . . 67

10. Scatter Diagrams of Male Mating Behavior
in Flocks 24C, 18, and $25 . . . . . . . .46$

11. Scatter Dlagrams of Male Mating Behavior In Flocks $23 \mathrm{C}$ and 10...... . . . . 77

12. Scatter Diagrams of Female Nating Behavior in Flocks 18, 25, and 23C ....... 82

13. Scatter Diagrams of Female Mat1ng Behavior

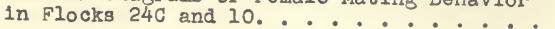




\section{INTRODUC TION ${ }^{1}$}

Among birds, soclal organlzation based on aggressive behavior is both wldespread and well documented. Although much of the information dealing with this facet of avian behavior is the result of studies on captive birds, fleld observations such as those reviewed by Coll1as (1944) and later by Allee (1950) Indicate that these behavioral phenomena are not merely a reflection of artificial confinement.

With an extensive background of both descriptive and analytical information about the social organization of the common domestic fowl, a study of the hlerarchal behavior of a closely-related species was desirable. The present investigation had a two-fold purpose: (1) to contribute to our

ITh1s Invest1gation was supervised throughout by the late Professor Warder Clyde Allee whose deep Interest, stimulation, and guldance was of the utmost benefit in the pursult of this study. Particular recognition $1 \mathrm{~s}$ given Dr. B. Ruffin Jones who of fered encouragement and advice during the preparation of the manuscript, and accepted the responsibilthe following staff members of the Department of Blology is a cknowledged: Drs. P. Brodkorb, J. C. Dickinson, J. Gregs, A. Grobman, and H. Wallbrunn. Dr. J. C. Drlggers of the Department of Poultry Husbandry offered many helpful suggestlons concerning care and breeding of the blrds. All postmortem examinations were made by the staff of the Poultry Diseases Laboratory. My wife, Hilda M. Banks, is due speclal mention for her moral and material contributions to this study, not the least of which included careful editing and
typing of this manuscript. 
knowledge of the hierarchal behavior of a previously unstudied group; (2) to compare this behavior with that of the related common domest1c fowl. C. O. Whltman (1898) suggested the study of behavioral phenomena from the standpoint of phylogenet1c descent. Recently, Lorenz (1950) has relterated this point of view. The ploneer study of this type was that of Whitman on the Columbidae, published posthumously in 1919. Helnroth (1910) also followed the phylogenetic point of view in h1s behavioral analysis of the Anatidae. Behavioral studles of representatives of three closely-related genera of grouse by J. W. Scott (1950) are phylogenet1c in nature. J. P. Scott (1950) compared the soclal behavior of wolves and dogs. The behavior of a number of invertebrates has been studied with the view of establishing phylogenetic relationshlps. The studies of Wheeler (1923) on a number of species of social insects, Petrunkevitch (1926) on splders, Emerson (1938) on the phylogeny of nest construction in colonial termites, and Crane (1949) on the comparative behavior of salt1cld splders, are noteworthy examples of investigations by students of Invertebrate blology. The selection of a form closely related to the common domestlc fowl for a study of social organization is in line with this approach.

Although the exact relationship between the Red Jungle Fowl and the common domestlc fowl is not completely clear, the evidence presently avallable indicates that these forms are closely related. Speculation concerning the origin of domestic 
breeds of poultry was f1rst crystallized by Darwin (1868). Later, Tegetmeler (1873) revlewed the evidence and arrived at the same conclusions as had Darwin. The hypothesis presented in these reports was that all breeds of the domest1c fowl Gallus gallus L. were developed from one of four w1ld species of the genus Gallus, namely the common Red Jungle Fowl known at that time as Gallus ferrugineus or Gallus bankiva.

The evidence on whlch both authors based thls hypothesis include the following considerations: the Red Jungle Fowl is the only species of the genus that is common, wideranging, can be tamed, produces fertile offspring with common domestic fowls, and closely resembles in structure, plumage, and volce, the Game fowl whlch are considered as the most generallzed domesticated breed. There are no indications, according to Dawin and Tegetmeler, that other living members of the genus gallus, or an extinct form, elther could or must necessarily have participated in this development.

Hutt (1949) summarlzes a second hypothesis which involves all four wild specles of Gallus in the development of the common domestic breeds. It is now known that hybrids between all species of the genus and domestic fowl are fertile. He further comments that the frequent repetition of Darwin's monophylet1c hypothesis has led to 1ts premature acceptance, and that it would appear that the problem awalts systematic breeding experiments before final judgement can be made. 
In a study of protein composition of egg whites obtained from Red Jungle Fowl, designated simply as Gallus gallus, and the common domest1c fowl, McCabe and Deutsch (1952) found a marked similarity between the two forms, a further indication of close taxonomic relationship. According to Delacour (1951) there are five geographlc races of the Red Jungle Fowl. All subspecles are well defined but, "The exact limits of distribution of the different subspecles . . need more precision, and no doubt extensive zones of intergradation exist between them."

In an attempt to 1dentify the race of Red Jungle Fowl with which the present report is concerned, a pair of skins was sent to the Museum of Comparative Zoology at Harvard College. The report of Mr. James Greenway, Jr., Curator of B1rds, reads in part as follows: "The Red Jungle Fowl resemble Gallus gallus gallus (L.) and G. g. spadiceus (Bonnaterre), races of Slam and Indo-China. . . It is probably imposible to determine exactly the origin of these birds. There 1s no indication in the plumage of mixture with domestic stock."2 The skins from which this estimation of the taxonom1c status of our colony of Red Jungle Fowl, to be referred to as Gallus gallus aubsp., were made are now deposited in the Florida State Museum, Gainesville, Florida.

${ }^{2}$ Personal communication, quoted with consent. 


\section{METHODS}

The nucleus from which our colony of Red Jungle Fowl was developed consisted of two groups of birds, obtalned on different dates. Both groups were representatives of one 1mportation of Red Jungle Fowl into th1s area from a fancybird breeder in Cal1fornia. The first consisted of two adult cocks, one cockerel, flve adult hens, and two pullets, recelved in September, 1951. In Febmary, 1952, an add1t1onal stock of $81 \mathrm{x}$ pullets and thirteen cockerels was obtained. Further additions to the colony resulted from matings in our pens.

Increase in colony size through breeding between individuals of the two orlginal groups followed three courses. Our maln concern was to ralse a sufficlently large number of Red Jungle Fowl to permit the study of groups of birds housed together in numbers comparable to those employed in studies of common domest1c fowl. Therefore, eggs were collected and stored in a refrigerator for up to but not longer than seven days. These were then set in a small, 100-egs incubator. Following standard poultry husbandry technlques, the set eggs were kept at from 99-1010 F, turned three to five times dally, and exposed to a humid environment, provided by finger bowls of water. 
During the winter perlod of October 1951 to February 1952, fertility was low and hatchability also proved disappointing. Modifications in temperature of the incubator and feed of the breeding birds, during this interval, were not fruitful. The explanation for this poor reproductive capacity was not clearly indicated, although the early morning frosts, frequent in this area during the winter, may possibly have been responsible. During the spring, summer, and early fall of 1952 and 1953, artificial incubation for twenty-one days proved more successful and some sixty chlcks were hatched. All incubator-hatched chlcks were brooded indoors, in small, 25-chick brooders. They were fed a ration of commerclal chick-starter mash and water. At four weeks of age, the chlcks were vaccinated against fowl pox, tested for pullorum disease, and moved to a pen in the same area in which the adult flocks were housed. Th1s pen was modified by 1solating an area $6 \mathrm{x}$ 4 leet with poultry netting. A 60-watt bulb, whose height above the floor could be controlled, provided the necessary heat. During this period, which lasted until the birds were from two to three months old, a ration of commerclal chickgrowing mash plus a small dally feeding of crushed grains was provided. Thereafter, the birds were assembled in varlous combinations, and their social behavior was observed. A second breeding method followed was to allow a broody jungle hen to hatch out her clutch of five to eight eggs and brood the chicks in the pen or yard in which the 
eggs were lald. For reasons which will be discussed in the observation section, this method was relatively unsuccessful in terms of increasing the colony size.

A modification of the above-described routine was to remove chicks to an electric brooder shortly after hatching. These were treated in a manner similar to chicks hatched in the incubator. Of the three methods, this one proved most successful. The hen-hatched chicks were easily reared to adulthood. One disadvantage of this method was that fewer chloks of the same age were produced as compared with the first method wherein egss were collected over a period of up to seven days before being set in the incubator.

Early in the study, adult birds were housed in poultry range shelters. These were $8 \times 10$ feet in width and length, walled with poultry netting and roofed with corrugated tin. In addition, a $4 \times 6$ foot shelter with a wirecovered extension $3 \times 20 \times 6$ feet in height, length, and width, respectively, was used to house temporarily the thirteen cockerels of the second group of Red Jungle Fowl referred to above. The latter house was used thereafter for surplus b1rds when these were present. In June, 1952, all birds except male flock 3 were moved to permanent wooden houses, esch divided into two $8 \times 10$ foot pens.

Extending the length of each pen was a dropping board, 2 feet above the floor and $3 \frac{1}{2}$-peet wide. Six inches above the latter were two or three $2 \times 4$ inch perches. The 
pens were also furnished with water palls, mash hoppers, and nests. Wood-shavings litter covered the dropping boards and pen floor. Each pen opened by a small door to an outdoor yard. The L-shaped yards were 20-feet wide and 38-feet long. Approximately 6 feet above the ground, 2-inch poultry netting served to enclose all outdoor yards from above.

The partition dividing each house into two pens was constructed partially of a wooden wall and a frame door with wire mesh covered with burlap completing the division. A hole, approximately one-foot square, was cut out of the burlap to afford a clear view of the pen floor; only the head of the observer was clearly visible to members of the flock undergoling observation.

Commercial poultry egg-laying mash and water were provided at all times. During observation periods, a mixture of whole grains composed of corn, wheat, and oats was dropped in a central area of the pen floor. Large, plastic wing badges with bold, black numbers on a yellow background proved excellent for rapid identification of the birds. Social interactions between individuals were recorded by writing down the particular wing badge number, and the type of aggressivesubmissive behavior exhibited. However, a more expeditious and quantitatively accurate method of recording this type of social behavior, used by Banks and Allee (1954), was followed when possible. This technique consisted of recording by volce all observed interactions on a magnetic tape-recorder 
and transcribing these data after the observation period. The advantage of such a recording method 18 obvious, and the volce of the observer had no apparent effect on the b1rds, Finally, slow-motion pictures of much of the hlerarchal behavior observed in this study were taken.

The observation period took the following course. After placing the mixed grains on the floor of the pen to be studied, the observer took a position in the adjacent pen. If the latter were occupled by a flock, it was carefully stimulated to move out to the yard, and the yard door was closed. No attempt was made to force all members of the flock undergoing observation into their pen. Experience indicated that such a procedure could disrupt the normal flock behavior for a considerable period of t1me. Furthermore, it was found to be unnecessary to lock all individuals of an observed flock 1nto their pen. Mot1vation for the grains was kept at a high level by feeding only during observation perlods. The sounds of the grains being dropped on the floor was usually sufficlent to attract all birds into the pen, providing the observer had taken hls position in the adjolning pen. The observation recording perlod varled from 10 to 30 minutes.

In the present work the aggressive-submissive interactions between pairs of Individuals were characterized by the following objective criteria: aggressive behavior man1fested by pecking or threatening by a dominant; submissive 
behavior evidenced by avolding movements by the subordinate individual. The peck is an overt action wherein the aggressive individual strikes the contact-mate with the b1ll. These blows generally fall on the head and neck reglons. Threats may be less obvious to the casual observer, but are characterized by Guhl (1953) as, ". . undelivered pecks or instances in which the dominant bird ralsed 1ts hackle or in an otherwise threatening manner caused the inferior to which this behavior was directed to avold the threatening b1rd." Avoldance behavior, exhiblted by a submissive ind1vidual, ranges from a mere dodging of the head to escape a peck to rapld and quite skillful flight.

Although the level of aggressive behavior is enhanced by the methods used in obtaining the data presented below, social interactions of the same type may occur in the absence of obvious competitive situations. A dominant bird may strike a subordinate whlle both are merely walking about the pen or yard. On the other hand, 1t is not the intent of this report to give the impression that the only activity to be seen in penned flocks of Red Jungle Fowl is the display of hierarchal behavior. Other types of activity not mentioned above and incidental to this study include such organizationally neutral behavior as preening, sand or dust bathing, roosting, random walking and scratching in the litter or so1l. The Red Jungle Fowl is an extremely excitable b1rd. When 1t became necessary to handle the b1rds, for 
example to move individuals from one pen to another, it was found most expedient to make such moves at nlght after the b1rds had gone to roost for a few hours. 


\section{OBSERVATIONS}

The data to be discussed below are based on observations collected from February, 1952, to December, 1954, on the following groups: four female flocks, three male flocks, one flock composed of White Leghom cocks, four heterosexual flocks, and one part-time heterosexual flock. The compos1tion of each and the inclusive dates and hours of study appear below. A complete tabulation of aggressive interactions for each group is given, and the social organizations are lllustrated by soclograms. Dach flock is discussed briefly and pertinent observations noted.

\section{SOCIAL HIERARCHY IN HEN FLOCKS}

\section{Flock 10A}

Observations of the hlerarchal behavior of this flock extended from November 24, 1953, to March 22, 1954, the group being studied on 74 days for a total period of 21 hours. A soclogram indicating the dominance-subordinance relationships of the nine hens comprising this flock at the end of the period is presented in Figure 1. The social organization exhib1ted is characteristic of the type based on peck-right dominance. When the birds are ranked according to the number of individuals dominated by a particular hen, the hierarchy 

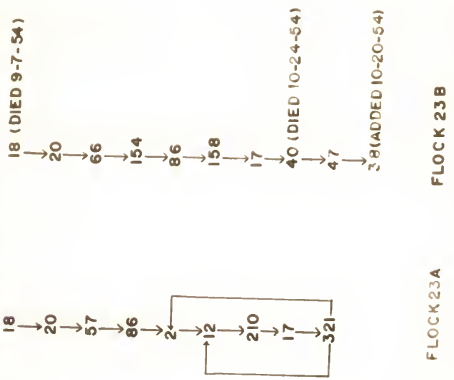

\begin{tabular}{l}
4 \\
0 \\
0 \\
0 \\
0 \\
\hline
\end{tabular}
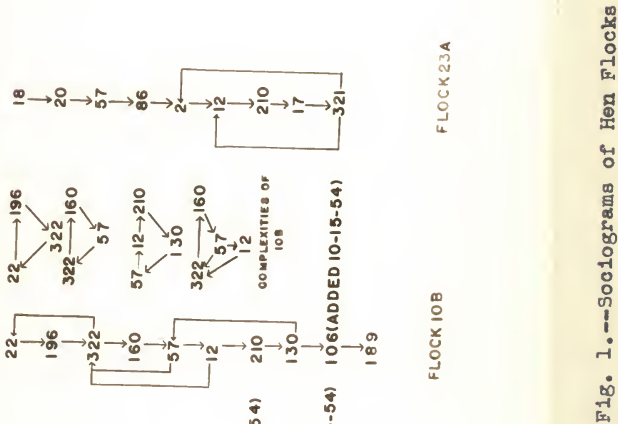

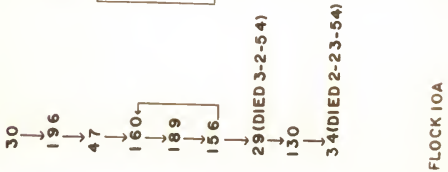


approaches a stralght line except for the triangular relat1onsh1ps ex1sting among hens 160, 189, and 156. A complete tabulation of the recorded soclal interactions appears in Tables 1 and 2. Observed social interactions, or pair contacts, among members of this flock totaled 2,067. The two forms of aggressive activity, pecking and threatening, each contributed about equally to the total.

\section{TABLF 1}

AGGRESSIVE INTERACTIONS IN FLOCK 10A: NUMBER OF OBSERVED PECKS

\begin{tabular}{|c|c|c|c|c|c|c|c|c|c|c|}
\hline \multirow{2}{*}{$\begin{array}{l}\text { Dom1nant } \\
\text { Hens }\end{array}$} & \multicolumn{10}{|c|}{ Subordinate Hens } \\
\hline & 30 & 196 & 47 & 160 & 189 & 156 & 29 & 130 & 34 & Total \\
\hline 30 & $\cdots$ & 93 & 60 & 48 & 53 & 37 & 45 & 37 & $\frac{11}{10}$ & 383 \\
\hline 196 & $\therefore$ & .. & 52 & 23 & 47 & 38 & 12 & 19 & 17 & 208 \\
\hline 47 & .. & .. & . & 28 & 13 & 21 & 16 & 26 & 15 & 119 \\
\hline 150 & . & .. & .. & .. & 24 & 34 & 33 & 23 & 18 & 101 \\
\hline 189 & •• & .. & .. & 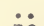 & .. & 34 & 29 & 12 & 10 & 85 \\
\hline 156 & ․ & . & $\cdots$ & 30 & .. & .. & 47 & 20 & 31 & 128 \\
\hline 29 & i* & . & $1 *$ & . & I* & 4* & .. & 20 & 23 & 50 \\
\hline 130 & .. & .. & .. & .. & .. & .. & . & .. & 23 & 23 \\
\hline 34 & & $\cdots$ & .. & & & & & .. & .. & 0 \\
\hline
\end{tabular}

*Peck-order violation.

The most striking aspect of the hierarchal behavior of these hens is the rigldity characteristic of their relative dominance-subordinance positions. Of the total number of observed pecks, approximately one per cent fall into the category known as revolts, or peck-order violations as defined by Holabird (1955). Hen 160, on three occasions, pecked 156, a b1rd that was clearly 1ts social dominant. One 
other hen in this flock, 29, committed seven peck-order violations, one of which was directed to hen 30 , another to 47 , a third to 189, and the remaining four to 156. None of these instances of peck-order violations resulted in reversals of dominance. Each was quickly followed by a countering peck or threat by the dominant hen.

\section{TABLE 2}

AGTRESSIVE INTERACTIONS IN FLOCK 1OA: NUMBER OF OBSERVED THREATS

\begin{tabular}{|c|c|c|c|c|c|c|c|c|c|c|}
\hline \multirow{2}{*}{$\begin{array}{c}\text { Dominant } \\
\text { Hens }\end{array}$} & \multicolumn{10}{|c|}{ Subordinate Hens } \\
\hline & 30 & 196 & 47 & 160 & 189 & 156 & 29 & 130 & 34 & Total \\
\hline 30 & $\cdots$ & 61 & 46 & 33 & 29 & 41 & 21 & 28 & 33 & 292 \\
\hline 196 & $\cdots$ & . & 63 & 41 & 38 & 45 & 18 & 28 & 12 & 245 \\
\hline 47 & $\cdots$ & $\cdots$ & $\cdots$ & 39 & 28 & 32 & 10 & 41 & 18 & $16 \overline{8}$ \\
\hline 160 & $\cdots$ & $\cdots$ & . & •. & 10 & $\cdots$ & 19 & 7 & 13 & 49 \\
\hline 189 & • & $\cdots$ & - & $\because$ & .. & 12 & 27 & 13 & 22 & 74 \\
\hline 156 & $\cdots$ & $\cdots$ & $\cdots$ & 53 & $\cdots$ & . & 12 & 21 & 14 & 100 \\
\hline 29 & $\cdots$ & $\cdots$ & $\cdots$ & $\cdots$ & $\cdots$ & $\cdots$ & .. & 22 & 11 & 33 \\
\hline 130 & $\cdots$ & $\cdots$ & $\cdots$ & $\cdots$ & $\cdots$ & $\cdots$ & .. & $\cdots$ & 9 & 9 \\
\hline 34 & $\cdots$ & . & . & 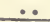 & $\cdots$ & . & .. & $\ldots$ & . & 0 \\
\hline
\end{tabular}

Those hens occupylng highest ranks in the hierarchy were also observed to exercise the peck-right most frequently. Were the individuals in this flock to be ranked according to the number of pecks delivered, the resulting hierarchy would follow the same order as that presented in the soclogram in Figure 1, with the exception of hen 156, whose numerical record would place her above 189. With respect to the record of observed threats presented in Table 2, the trend is in the same direction as that of the pecks, but in this instance the 
assoclation between numbers of threats delivered and soclal status is not as close.

Three males were perlodically introduced into this flock for breeding purposes. The effect of thls procedure on the hlerarchal behavior of the hens, and a report of the breeding behavior observed is presented later. However, the data presented above represent observations carried on in the absence of the three males.

\section{Flock 10B}

Observations of this flock extended from June 14 , 1954, to November 19, 1954, for a comblned total of 18 hours distributed over 107 days. Originally composed of nine hens, the flock was increased to ten Individuals with the introduction of 106 on October 15, 1954. A tabulation of pecks and threats is presented in Tables 3 and 4, respectively. An examination of the structure of the organization as found in Figure 1, reveals a marked departure from a straight-1ine hlerarchy. For the sake of clarity, the complex dominancesubordinance relationships reverled in the soclogram of flock $1 O B$ are 1llustrated individually in Figure 1. Two simple triangular relationships are found, one consisting of hens 22,196 , and 322 , and the other of 322,160 , and 57 . A third complication 1s that involving 57, 12, 210, and 130. The final deviation from a stralght-line hierarchy is an extension of the second triangle referred to above, with the addition of 12, subordinate to 160 and 57, but dominant to 322 . 
The sociogram may be sald to represent a geometrical type of peck order (Foreman, D. In l1tt.).

\section{TABLE 3}

AGGRESSIVE INTERACTIONS IN FLOCK IOB: NUMBER OF OBSERVED PECKS

\begin{tabular}{|c|c|c|c|c|c|c|c|c|c|c|c|}
\hline Dom Inant & & & & Subc & ord & nete & Hens & & & & \\
\hline Hens & 22 & 196 & 160 & 57 & 12 & 322 & 210 & 130 & 106 & 189 & Total \\
\hline 22 & . & 37 & 18 & 23 & I7 & 45 & 28 & 18 & 38 & 49 & 214 \\
\hline 196 & $\cdots$ & .. & 42 & 19 & 32 & 27 & 18 & 21 & 12 & 23 & 184 \\
\hline 160 & $\bullet$ & $\cdots$ & .. & 14 & 27 & $\bullet$ & 32 & 40 & 8 & 15 & 136 \\
\hline 57 & $\bullet$ & $\bullet$ & $\Leftrightarrow$ & . & 38 & 17 & 27 & I* & 29 & 18 & 130 \\
\hline 12 & $\ldots$ & - & . & . & .. & 30 & 17 & 22 & 21 & 11 & 101 \\
\hline 322 & 97 & •. & 83 & •• & .. & $\cdots$ & 13 & 11 & 15 & 8 & 227 \\
\hline 210 & .. & •. & $\cdots$ & 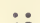 & •. & $\cdots$ & . & 12 & 12 & 20 & 44 \\
\hline 130 & . & •. & . & 28 & •. & $\cdots$ & $\cdots$ & .. & 17 & 7 & 52 \\
\hline 106 & - & - & $\cdots$ & - & - & .. & $\cdots$ & .. & . & 58 & 58 \\
\hline 189 & $\ldots$ & .. & .. & .. & .. & $\cdots$ & $\cdots$ & .. & $\cdots$ & . & 0 \\
\hline
\end{tabular}

"Peck-order violation.

TABLE 4

AGGRESSIVE INTERACTIONS IN FLOCK IOB: NURBER OF OBSERVED THREATS

\begin{tabular}{|c|c|c|c|c|c|c|c|c|c|c|c|}
\hline \multirow[t]{2}{*}{$\begin{array}{l}\text { Dom Inant } \\
\text { Hens }\end{array}$} & \multicolumn{11}{|c|}{ Subordinate Hens } \\
\hline & 22 & 196 & 160 & 57 & 12 & 322 & 210 & 130 & 106 & 189 & Total \\
\hline 22 & $\cdots$ & 58 & 33 & 17 & 23 & 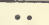 & 28 & 21 & 28 & 18 & 226 \\
\hline 196 & $\cdots$ & .. & 76 & 13 & 15 & 17 & 17 & 31 & 17 & 10 & 196 \\
\hline 160 & $\cdots$ & $\cdots$ & . & 28 & 32 & $\because$ & 17 & 36 & 33 & 15 & 161 \\
\hline 57 & $\cdots$ & •• & . & . & 18 & 12 & 7 & •・ & 12 & 6 & 55 \\
\hline 12 & $\ddot{0}$ & $\cdots$ & & . & .. & 13 & 23 & 8 & 18 & 3 & 65 \\
\hline 322 & 128 & $\cdots$ & 140 & . & . & •. & 27 & 18 & 12 & 29 & 354 \\
\hline 210 & $\cdots$ & $\cdots$ & $\cdots$ & $\because$ & - & $\cdots$ & $\cdots$ & 12 & 30 & 14 & 56 \\
\hline 130 & $\cdots$ & - & $\cdots$ & 11 & •. & . & $\cdots$ & . & 14 & 19 & 44 \\
\hline $\begin{array}{l}100 \\
189\end{array}$ & $\cdots$ & $\cdots$ & $\cdots$ & $\cdots$ & $\cdots$ & $\cdots$ & $\cdots$ & $\cdots$ & $\cdots$ & 43 & 43 \\
\hline & $\cdots$ & $\cdots$ & $\cdots$ & $\cdots$ & 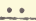 & 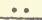 & $\ddot{\circ}$ & $\cdots$ & .. & .. & 0 \\
\hline
\end{tabular}


Hen 106 was arbitrarily added approximately four months after the flock was assembled. It should be noted that all resident hens except 189 won peck-rlght over 106. Th1s fact 18 of interest for two reasons. At the time of Introduction, 106 was four and one-half months old and therefore the youngest individual present. The dominance of 106 over 189 is contrary to findings to be reported later, on similar introductions wherein the younger of two individuals is generally found to be subordinate to the older of the contact pair. A second consideration is that members of an organized flock tend to win over singly-introduced strangers 1f the introduction occurs in the home pen of the organized flock. The explanation of the dominance of 106 over 189 rests on the fact that the latter became broody late in June and continued in that condition throughout the study.

One of the concomitants of broodiness in other birds, such as the common domestic hen and the pigeon, is a reduction in the secretion of gonadal hormones (R1ddle and Bates, 1939). This reduction, if such did in fact occur in hen 189, was reflected in a decrease in aggressive behavior. Collias (1943) found that male hormone, as indicated by comb $81 z e$, was a major factor in the ability of domestic hens to win initial contests. Such an explanation must remain provisional unt1l endocrine studies are undertaken on the Red Jungle Fowl, but if such were the case, it would offer an interpretation for the success of 106, a young, newly-1ntroduced hen, 
In gaining dominance over 189, a fully-adult, long-t1me resldent of the flock. Further support for this reasoning rests on the reversal of dominance-subordinance relations between 130 and 189. The latter held peck-rlght over 130 when both were members of flock $10 \mathrm{~A}$, and during the first week of observation of the present flock. After 189 became broody, 130 successfully challenged her dominance and executed the sole example of reversal in social status found in this study of hen flocks.

The stabllity of the hierarchy in Red Jungle Fowl hens 18 further demonstrated by the small number of peckorder violations w1tnessed in th1s flock. Hen 22 committed four violations against 322, none of which resulted in alteration of the hierarchy. In addition, 57 pecked 130, her soclal dominant, on one occasion. Th1s peck-order violation was quickly retallated by 130 . Of the total number of observed pecks recorded during the 18 hours in which flock $10 B$ was studied, only about 0.4 per cent could be classifled as being counter to the social organization.

The correspondence between social status and observed agsressive activity is less clear in this flock than 1t was in flock 10A. The trend, however, remains in the direction of more frequent use of the peck-right in those hens holding high social rank. An interesting exception to this tendency 1s shown by the record of hen 106. Though dominant only to 189, the total number of pecks delivered by 106 compares 
favorably with that of 130 and 210, both of whlch were dom1nant to three individuals.

\section{Flock 23A}

A total of 21.2 hours, distributed over 65 days was spent in the observation of this flock. Study began on August 9, 1953, and extended to November 2, 1953. A tabulation of the social interactions witnessed is presented in Tables 5 and 6 for pecks and threats, respectively. A soclogram of the hlerarchy so determined appears in Flgure 1. It will be noted that this flock is organized in a simple, straight-line hlerarchy, except for the dominance of 321 over 2 and 12. Aslde from these deviations, the hierarchal behavior of these hens 18 straight-forward and typical of the peck-right form of soclal organization. No peck-order violations were observed.

\section{TABLE 5}

AGGRESSTVE INTERACTIONS IN FLOCK 23A: NUMBER OF OBSERVED PECKS

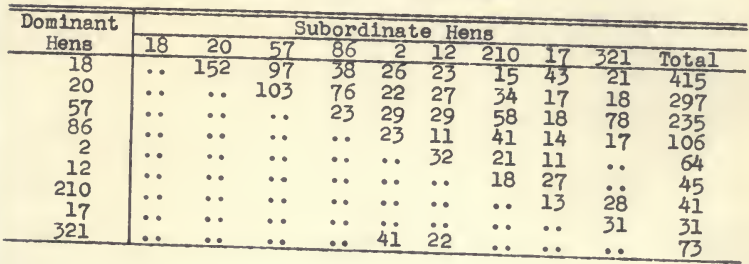


TABLE 6

AGTRISSIVE INTERACTIONS IN FLOCK 23A: NUMBER OF OBSERVED THREATS

\begin{tabular}{|c|c|c|c|c|c|c|c|c|c|c|}
\hline \multirow{2}{*}{$\begin{array}{c}\text { Dominant } \\
\text { Hens }\end{array}$} & \multicolumn{10}{|c|}{ Subordingte Hens } \\
\hline & 18 & 20 & 57 & 86 & 2 & 12 & 210 & 17 & 321 & Total \\
\hline 18 & $\cdots$ & 19 & 39 & 11 & 18 & 21 & 33 & 30 & 25 & 196 \\
\hline 20 & .. & .. & 42 & 37 & 47 & 40 & 18 & 28 & 33 & 245 \\
\hline 57 & . & .. & .. & 29 & 17 & 39 & 41 & 18 & 26 & 170 \\
\hline 86 & $\cdots$ & .. & .. & .. & 38 & 29 & 33 & 16 & 52 & 168 \\
\hline 2 & .. & -. & .. & .. & .. & 31 & 28 & 41 & $\cdots$ & 100 \\
\hline 12 & . & . & . & .. & $\cdots$ & .. & 22 & 47 & 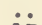 & 69 \\
\hline 210 & - & -. & .. & -. & .. & .. & .. & 28 & 17 & 45 \\
\hline $\begin{array}{r}17 \\
321\end{array}$ & $\cdots$ & - & . & $\because$ & $\ddot{\ddot{z}}$ & $\ddot{i}$ & .. & .. & 42 & 42 \\
\hline & & & & & & & - & $\cdots$ & . & 58 \\
\hline
\end{tabular}

The alpha, or highest-ranking individual, 18, the oldest female of the colony, exercised her peck-right vigorously and persistently, and contributed approximately one third of the total number of pecks recorded for the flock. The agressive behavior of 18 was of such a severe nature that some subordinate hens responded to her in an ambiguous manner. She was the only individual to which subordinates gave the "sex crouch" as a manifestation of submissive behavior. Th1s behavior pattern is erequently seen in receptive hens in the presence of a male and consists typically of a lowering of the body into a squatting attltude, wings ralsed and held away from the body; neck, head, and beak extended horizontally above the floor. The sex crouch was exhibited by 2, 12, 210, and 17 in interactions with 18. Although extremely aggressive, 18 did not appear masculin1zed, 1.e., her comb was no larger than that of other hens 
and she produced and incubated normel clutches of eggs.

\section{Flock 23B}

Study of the hlerarchal behavior of flock 23B extended from June 15, 1954, to November 23, 1954, for a total of 18.1 hours of actual watching and recording of behavior distributed over 109 days. Tabulations of the aggress1ve behavior recorded appear in Tables 7 and 8 for pecks and threats, respectively. A soclogram of the organization of this flock, lllustrated in Flgure 1 , reveals a stralght-1ine dominance-subordinance hlersechy. The alpha hen, 18, held her position unt1l september 7 , at which t1me she died of chronic pullet disease. It is interesting to note, in this respect, that although 18 became distinctly less vigorous in all aspects of her observed behavior, between the time this flock was assembled and her death, there were no known peckorder violations directed to 18. During June, 40 was observed to respond to the aggressive approsches of 18 by exhlbiting the sex crouch on two occasions. Following the death of 18, the second-ranking individual in the hlerarchy, 20 , became alpha hen.

Approximately one month before observation of this flock was discont1nued, 38, a five-month-old pullet was introduced. In this instance, the young, newly-1ntroduced 1ndividual was defeated in pair-contacts w1th all resident flock members and assumed omega status in the hlerarchy, the normal, 
expected outcome of such a procedure. Hen 40 died of 1 ymphomatos 1s on october 24, 1954. Although she was observed in pair-contact with 38 on only elght occaslons 40 was clearly dominant to 38 , the newly-introduced pullet.

\section{TABLE 7}

AGGRESSIVE INTERACTIONS IN FLOCK 23B: INUMBER OF OBSERVED PECKS

\begin{tabular}{|c|c|c|c|c|c|c|c|c|c|c|c|}
\hline \multirow{2}{*}{$\begin{array}{c}\text { Domlnant } \\
\text { Hens }\end{array}$} & \multicolumn{11}{|c|}{ Subordinate Hens } \\
\hline & 18 & 20 & 66 & 154 & 86 & 158 & 17 & 40 & 47 & 38 & ToteI \\
\hline 18 & $\bullet$ & 58 & 22 & 31 & 18 & 12 & 28 & 34 & 13 & 8 & 224 \\
\hline 20 & •- & $\ldots$ & 37 & 28 & 47 & 49 & 52 & 46 & 33 & 21 & 313 \\
\hline 66 & . & . & •. & 42 & 18 & 31 & 41 & 23 & 14 & 10 & 179 \\
\hline 154 & $\bullet$ & $\ldots$ & $\bullet$ & -. & 14 & 26 & 17 & 13 & 22 & 7 & 99 \\
\hline 86 & - & $\ldots$ & $\ldots$ & •・ & $\bullet$ & 22 & 18 & 22 & 6 & 8 & 76 \\
\hline 158 & $\cdots$ & $\ldots$ & $\cdots$ & .. & $\bullet$ & •• & 13 & 19 & 23 & 5 & 60 \\
\hline 17 & .. & $\ldots$ & $\cdots$ & -. & $\bullet$ & $\cdots$ & $\bullet$ & 21 & 18 & 11 & 50 \\
\hline 40 & •. & $\bullet$ & $\bullet$ & -. & -. & • & •. & $\cdots$ & 17 & 3 & 20 \\
\hline 47 & .. & .. & .. & .. & .. & $\cdots$ & .. & $\cdots$ & .. & 2 & 2 \\
\hline 38 & & 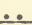 & . & $\ldots$ & . & $\cdots$ & .. & •. & -. & .. & 0 \\
\hline
\end{tabular}

TABLE 8

AGGRESSIVE INTERACTIONS IN FLOCK 23B: NUMBER OF OBSERVED THREATS

\begin{tabular}{|c|c|c|c|c|c|c|c|c|c|c|c|}
\hline \multirow{2}{*}{$\begin{array}{c}\text { Dom Inant } \\
\text { Hens }\end{array}$} & \multicolumn{11}{|c|}{ Subordinate Hens } \\
\hline & 18 & 20 & 66 & 154 & 86 & 158 & 17 & 40 & 47 & 38 & Total \\
\hline 18 & $\cdots$ & 17 & 31 & 20 & 17 & 18 & टे & 23 & I4 & 11 & 172 \\
\hline 20 & .. & .. & 72 & 58 & 47 & 60 & 120 & 33 & 41 & 42 & 473 \\
\hline 66 & .. & . & $\cdots$ & 51 & 38 & 14 & 23 & 18 & 21 & 31 & 196 \\
\hline 154 & - & . & .. & $\bullet$ & 49 & 31 & 34 & 28 & 17 & 10 & 169 \\
\hline 86 & . & . & .. & •• & $\bullet$ & 33 & 28 & 16 & 18 & 14 & 109 \\
\hline 158 & - & . & . & .. & $\ldots$ & $\cdots$ & 47 & 30 & 21 & 17 & 115 \\
\hline 17 & . & . & $\cdots$ & $\cdots$ & .. & $\bullet$ & $\cdots$ & 31 & 20 & 22 & 73 \\
\hline 40 & $\cdots$ & $\cdots$ & $\cdots$ & $\cdots$ & $\cdots$ & $\cdots$ & $\cdots$ & $\cdots$ & 21 & 5 & 26 \\
\hline 47 & $\cdots$ & $\cdots$ & - & $\cdots$ & $\cdots$ & $\cdots$ & $\cdots$ & . & . & 18 & 18 \\
\hline 38 & $\cdots$ & $\cdots$ & $\cdots$ & $\cdots$ & $\bullet$ & .. & $\ldots$ & .. & .. & $\cdots$ & 0 \\
\hline
\end{tabular}


Relat1ve Soc1al Status of Hens Together in Two Flocks

Twelve of the twenty-s1x hens used in this study were members of two flocks. The hierarchal behavior of these individuals may be viewed from two aspects: (a) the relative dominance-subordinance relationships of those hens that were both members of the same two flocks, and (b) the status of each such hen in the hlerarchy of the two flocks of which it was a member.

Table 9 presents a list of birds that were residents of the same two flocks, and Indicates the dominancesubordinance relationships between both individurls in each flock. It is clear from this analysis that once dominance becomes established between any pair of Individuals, transfer to another flock or the introduction of new hens into the same pen has no effect on the dominance-subordinance relationships previously determined. The one exception is the case of 189 and 130. When they were members of flock $10 \mathrm{~A}, 189$ was dominant to 130. Approximately three months later, when both Individuals were members of flock 10B, 130 became dom1nant over 189. This reversal in social status has been discussed previously.

It w1ll be noted that only eleven hens are listed in Table 9 as being members of two flocks. The twelfth hen, 47, was a member of flocks $10 \mathrm{~A}$ and $23 \mathrm{~B}$, the only 1ndividual so arranged. 
TABLE 9

RELATIVE DOMINANCE-SUBORDINANCE POSITIONS OF HENS TOGETHER IN TWO FLOCKS ${ }^{2}$

\begin{tabular}{cc}
\hline F1rst Flocks & Second Flocks \\
\hline 10 A & $10 \mathrm{~B}$ \\
\hline $196>150$ & $196>160$ \\
$196>189$ & $196>189$ \\
$196>130$ & $196>130$ \\
$160>189$ & $160>189$ \\
$160>130$ & $160>130$ \\
$189>130$ & $130>189 \mathrm{~b}$ \\
\hline $23 \mathrm{~A}$ & \\
\hline $18>20$ & $18>23 \mathrm{~B}$ \\
$18>86$ & $18>86$ \\
$18>17$ & $18>17$ \\
$20>86$ & $20>86$ \\
$20>17$ & $20>17$ \\
$86>17$ & $86>17$ \\
& \\
\hline $23 \mathrm{~A}$ & $10 \mathrm{~B}$ \\
\hline $57>12$ & $57>12$ \\
$12>210$ & $57>210$ \\
\hline
\end{tabular}

a $>$ dominant over. $\mathrm{b}_{\text {Reversal. }}$

The status of each bird in the hierarchy of the two flocks of which 1t was a member is presented in Table 10. The relative position of each hen is given in terms of numbers of Individuals dominant or subordinate to a particular bird. In general, there are no striking differences in the status of a given hen in the A, or flrst set of flocks, and the later-organized B flocks. The records of 189 and 47 are exceptional in this respect. The case of 189 has already been discussed, and 1 t is of interest here merely to note 
that when a member of flock $10 \mathrm{~A}, 189$ ranked m1dway in the organlzation of that flock. Later, when a member of $10 \mathrm{~B}$, 189 fell to omega status.

TABLE 10

SOCIAL STATUS OF HENS WHICH WERE MEMBERS OF TWO FLOCKS

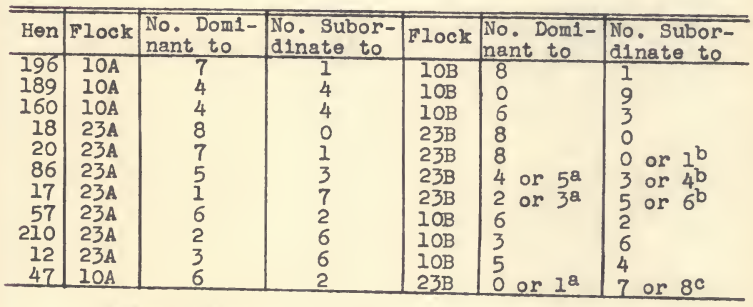

$a_{\text {After }}$ addition of 38 .

before death of 18 .

cBefore death of 40 .

The case of 47 is also worthy of note. When a member of $10 \mathrm{~A}, 47$ was dominant to $\mathrm{s} 1 \mathrm{x}$ hens and subordinate only to the alpha and beta members of that flock. On belng transferred to 23B, 47 lost inftial encounters with all flock members, becoming omega hen of the organization. When 38 was added to 23B, late in the study, 47 won peck-right over 38. This last observation lends support to the generalization that strange Individuals added singly to an organized flock tend to lose initial pair-contacts with resident hens. 
The Effect of Home Territory on Soc1al Status

Table 11 1llustrates the composition of the second set, or " $B$ " Plocks. Flock $\angle O B$ was mado up of four birds that had been members of 10A. Hens 196, 160, 130, and 189 had long experience with the pen in which they were housed. Into this pen, 57, 12, and 210 from flock $23 \mathrm{~A}$ were introduced. The remaining nembers of $10 B, 22,322$, and 106, were transferred from a surplus, previously unobserved group. To the last $s i x$ hens, the pen housing $10 B$ constituted a physleally strange area. All but 106 were introduced into pen $10 B$ on the evening before observation of this flock was begun.

\section{TABLE 11}

FLOCK REORGANIZATION SCHEME*

\begin{tabular}{|c|c|}
\hline Flock $10 \mathrm{~B}$ & Flock 23B \\
\hline 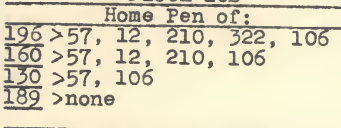 & $\begin{array}{l}\text { Home Pen of: } \\
\frac{18}{20}>66,154,158,40,47 \\
\frac{86}{86}>158,154,158,40,47,38 \\
\frac{17}{17}>40,47,38,38\end{array}$ \\
\hline $\begin{array}{l}\text { Introduced into } 10 \mathrm{~B} \\
\text { from 23A: }\end{array}$ & $\begin{array}{l}\text { Introduced into } 23 \mathrm{~B} \\
\text { from } 10 \mathrm{~A}:\end{array}$ \\
\hline $\begin{array}{l}57>189 \\
12>130, \frac{189}{189} \\
210>130, \underline{189}\end{array}$ & $47>$ none \\
\hline $\begin{array}{l}\text { Introduced into 10B } \\
\text { from Sumplus Pen: } \\
22>196,150,130,189 \\
322>189 \\
106>189\end{array}$ & $\begin{array}{l}\text { Introduced Into } 23 \mathrm{~B} \\
\quad \text { from Surplus Pen: } \\
66>86,17 \\
154>\frac{86}{17}, 17 \\
158>\frac{17}{40>\text { none }} \\
38>\text { none }\end{array}$ \\
\hline
\end{tabular}

- See text for explanation. Hens underlined were longtime residents of the pen. $>=$ dominant over. 
Flock $23 B$ was similarly composed of four hens that as members of $23 \mathrm{~A}$ had long experience with the pen. These were $18,20,86$, and 17 . One bird, 47 , was introduced from $10 \mathrm{~A}$ and the remaining five were transferred from the unobserved surplus flock. All birds to which pen 23B was an unfamiliar area were introduced as a group on the same evening, except for hen 38, which was added about one month before observation of this flock was discontinued.

It is of interest to examine the resulting hierarchies of $I O B$ and $23 B$ to determine whether hens to whom the pen was a familiar area were more successful in winning peck-right than were those individuals to whom the pen constituted a strange territory.

In flock 10B, 22 won dominance over all four hens that were long-time residents in the pen. of the remaining introduced birds, 12 and 210 won over two long-time residents, and 57, 322, and 106 over one. Among the hens with long experience in this pen, 196 won over five introduced birds, 160 over four, and 130 over two. 189 falled to gain peckright over any of the introduced birds.

In flock $23 \mathrm{~B}$ only three of the introduced blrds gained dominance over long-time residents. Hens 66 and 154 won over 86 and 17, and 158 became dominant to 17. Three birds, 47, 40 , and 38 , falled to win over any of the pen-experienced individuals. Both 18 and 20, long-time residents of the pen, won over all introduced birds. (18 died before 38 was added 
to the flock.) Hens 86 and 17 were moderately successful in winning over introduced birds.

The trend indicated by these data is in the direction of success in winning crucial initial contacts associated with familiarity or long-time residence in the given pen. The exceptions (particularly that of 22 in flock $10 B$ ) and the small number of cases prevent a generalization. From Information to be reported later, it is known that strange hens introduced singly into organized flocks invariably lose to most or all resident hens. The fact that in the present instance, birds were added in considerable numbers on one night may explain the fallure of long-time residents to benefit from the advantage of familiarity with the pen and win dominance over all introduced birds. 


\section{SOCIAL ORGANIZATION IN JUNGLE FOWL COCKS}

\section{Flock 3}

Th1s flock was composed of twelve cockerels and one cock. The former were part of a larger group recelved early In February 1952, and were three and one-half months old at this time. The latter was the oldest male of the colony; he was a mature adult when obtained in September 1951. During the time in which the observations to be discussed were collected, this flock was housed in a 4 x 6 foot frame shelter, one side of which extended into a wire-covered munway $3 \times 20$ $x 6$ feet in height, length, and width, respect1vely.

Before describing the social hierarchy of this group, some comment regarding 1ts general behavior is pertinent. The male Red Jungle Fowl is highly pugnacious and exc1table. The combination of these two complex characteristics, assoc1ated with the small living quarters in which they were kept, made for an extremely sensitive group. Particular care was exerclsed in approaching the pen, and in providing the mixed grains about which aggressive-subm1ssive interactions were focused. A considerable amount of aggressive act1vity was observed in the runway, some distance from the feoding area. As in flocks of Red Jungle Fowl hens, hierarchal behavior was primarily exhibited in pecking, threatening, and avolding reactions. In addition to these, "waltzing" and crowing 
contributed to the overall plcture of a highly aggressive soclal organization. These latter factors will be discussed below.

Flock 3 was observed closely from February 18 to August 12, 1952, for a total of 31.7 hours distributed over 127 days. A tabulation of observed pecks and threats appears In Tables 12 and 13, respect1vely. Three soclograms of the hierarchy appear in Figure 2. Several aspects of these data mer1t cons1deration. Or a total of 2,833 observed pecks, 170 or 6 per cent fall 1nto the peck-order violation category. The dominance-subordinance stablilty, show so clearly in the female hlerarchy presented earlier, is in the present case incomplete, as evidenced by five instances of reversal in dominance. In addition, dominance-subordinance relationships between four pairs of oockerels were of a recurrent nature. These latter are indicated in the soclograms by broken Iines. The structure of the hierarchy varled during the study perlod, but can be characterized as nonlinear, 1.e., contalning complicated peck-rlght relat1onships. A soclogram for three divisions of the total study time is helpful in depicting the new dominance orders created by the following reversals in soclal status: 11 over 4 (March 6), 8 over 4 (April 24), 6 over 12 (May 13), 12 over 3 (June 1I), and 4 over 7 (July 28). In each of these cases, the cockerel over which a reversal in dominance was galned was clearly dominant to the soclallymoblle bird prior to the reversal. Subsequent observation 
Indicated no peck-order violations by the formerly dominant individual against the new dominant of a given pair.

\section{TABLE 12}

AGGRESSIVE INTERACTIONS IN FLOCK 3: NUMBER OF OBSERVED PECKS ${ }^{\circ}$

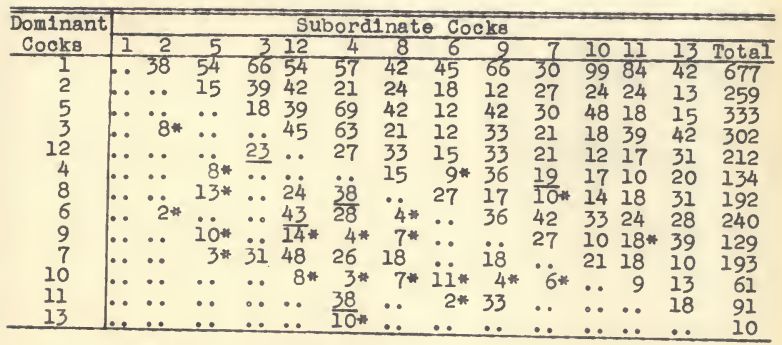

ounderlining indicates reversals.

*Peck-order violation.

This situation stands in marked contrast to that presented by the recurrent reversals in dominance relations between 7 and 3,9 and 7,12 and 7 , and 8 and 12. Table 14 presents a summary of the exchange of dominance between these pairs of cockerels. For the sake of clarity, one series of reversals w1ll receive comment with the 1mplication that all followed the same general course.

From February 18 to April 10, male 9 was observed in pair-contact with 7 on sixteen occasions. In every instance, 9 appeared clearly dominant to 7 . However, on April 11 an unobserved reversal had occurred, and between this date and June 


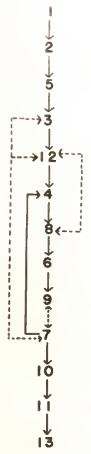

2-18 TO 3-5

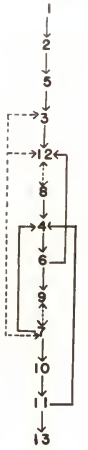

3-6 TO 5-14

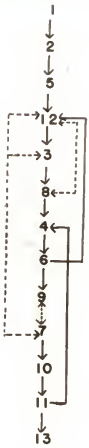

5-15 TO8-12-54

F1g. 2.--Soclograms of Male Flock 3 
20, 7 exercised peck-rlght over 9 in elghteen different palrcontacts. The study perlod of June 21 revealed a second reversal between this pair, with 9 again in the dominant position. Eleven social Interactions were observed between 9 and 7 from June 21 to August 12. In every case, 9 was the dominant member of the contact pair.

\section{TABLE 13}

AGGRESSIVE INTERACTIONS IN FLOCK 3 : NUMBER OF OBSERVED THREATS*

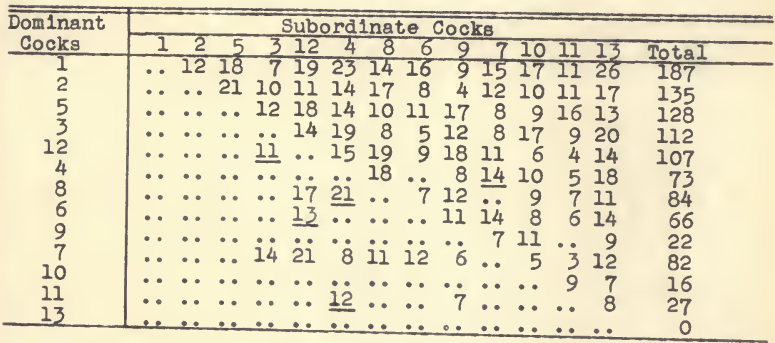

*Underlining Indicates reversals.

A prominent aspect of the soclal behavior exhiblted by this group was the display of waltzing or strutting. Domm and Davis (1948) expressed the 1dea that the waltz is used by domest1c roosters as a method of sex recognit1on. Th1s matter is discussed later in the section on male mating behavior. The display of waltzing behavior by Red Jungle Fowl hens in inltial palr-contests w1th other hens indlcated that the waltz may also be an expression of aggressive behavior. 
TABIE 14

RECURRENT REVERSALS IN DOMINANCE RECORDED IN FLOCK 3

\begin{tabular}{c|c|c}
\hline $\begin{array}{c}\text { Dominant } \\
\text { Cock }\end{array}$ & $\begin{array}{c}\text { Subordinate } \\
\text { Cock }\end{array}$ & $\begin{array}{c}\text { Inclus1ve } \\
\text { Dates }\end{array}$ \\
\hline 7 & 3 & $2 / 18$ to $2 / 24$ \\
3 & 7 & 25 to $3 / 14$ \\
7 & $3 / 15$ to $5 / 2$ \\
3 & 7 & $5 / 3$ to $8 / 12$ \\
\hline 9 & 7 & $2 / 18$ to $4 / 10$ \\
7 & 9 & $4 / 11$ to $6 / 20$ \\
9 & 7 & $6 / 21$ to $8 / 12$ \\
12 & 7 & $2 / 18$ to $3 / 2$ \\
7 & 12 & $3 / 3$ to $5 / 8$ \\
12 & 7 & $5 / 9$ to $6 / 4$ \\
7 & 12 & $6 / 5$ to $8 / 12$ \\
\hline 8 & 12 & $2 / 18$ to $4 / 15$ \\
12 & 8 & $4 / 16$ to $4 / 28$ \\
8 & 12 & $4 / 29$ to $6 / 3$ \\
12 & 8 & $6 / 4$ to $8 / 12$ \\
\hline
\end{tabular}

That the waltz was definitely an aspect of aggressive behavior in the cockerel flock under discussion may be seen from the data presented in Table 15. This tabulation $1 \mathrm{~s}$ arranged so that those birds displaying the waltz are 11 ted in the left-hand column; those to which the waltz is directed appear in the upper row, and the flgures indicate the number of times the waltz was observed between a given pair of males. There are 78 possible unidirectional dominance relationships in this flock of thirteen males. In all except three pairs, dominants were observed to address the waltz to subordinates. There were only two instances of waltzing contrary to the soclal hierarchy as determined by pecking. Male 11 was observed to waltz 6 on two different occasions, and the latter clearly 
held peck-right over the former. Although the number of waltzes observed was about half that of observed pecks, the evidence is such that if the birds were arranged according to the "waltz-right," the resulting organization, with the exceptions noted above, would be 1dentical to that based on peck-right.

\section{TABLE 15}

AGGRESSIVE INTERACTIONS IN FLOCK 3: NUMBER OF OBSERVED VALTZES\&

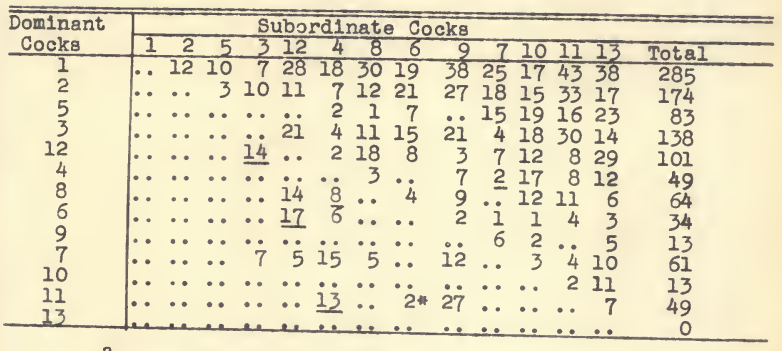

${ }^{a}$ Underlining indicates reversals.

*Waltz in violation of peck-order.

Mention has been made of crowing in thils flock as a manifestation of aggressive behavior. In general, subord1nate males were threatened while crowing, if a dominant were near. The peck-order was dramatically 1llustrated many times by the abrupt suspension of an incomplete crow given by a low-ranking cockerel when approached by a belligerent dominant individual. 
A final 1tem of interest was the absolute dominance of 1 , the oldest cock, over all other flock members. Th1s dominance was exerclsed frequently and vigorously. At times during observation perlods, it appeared that 1 expended more effort in pecking and waltzing his subordinates than he did in leeding.

\section{Flock 24A}

Th1s group of ten mature Jungle Fowl cocks was assembled on the evening of November 12, 1952. Five of the males had been under observation when they were members of flock 3 . The remaining five were previously unobserved. Study of hlerarchal behavior began on the next day, and was continued until March 20, 1953, for a total of 26 hours distributed over 89 days. During the first week, although few social interactions were noted, it was apparent that many contests for the establishment of peck-right were taking place. All but 1 and 3 showed evidence of fighting in the form of wounds on comb and wattles. The flock, whlch generally stayed in the outdoor jard, was eas1ly disturbed by the presence of the observer in the adjoining pen. Based on experlence with hens, no effort was made to force the cocks into the pen. Deprivation of grains in addition to increasing famillarity with the pen were factors which undoubtedly helped to diminish the negative response of the birds to the pen when observations were being recorded, and during the second week the cocks entered the pen and fed readily. 
A tabulation of observed pecks and threats is presented in Tables 16 and 17, respectively. Two sociograms 1llustrating the organization in this Plock appear in Figure 3. This group resembles flock 3 in the large number of peck-order violations. There were ten complete reversals in dominance, elght of which involved cock 1 . It will be recalled that 1 was the despotic alpha cock of flock 3 . Soon after adequate records were collected 1t was clear that 1 was also the top-ranking male in this group. It was therefore of great interest to note that 1 lost peck-right to 14 on January 19. This reversal was not witnessed but inferred from wounds on both 1 and 14. That 1 had been defeated was equally obvlous from the complete change In his behavior and posture. By January 28, all other flockmates except 19 were observed in interactlons with 1; all were dominant over this former alpha cock. No interactions were witnessed between 1 and 19, the omega 1ndividual. From the above-mentloned date unt1l study of this flock was discontinued, 1 was a disassimllated member of the organization. He rarely entered the pen during observation periods when grains were made available, and on those few occasions, he was chased out to the yard by a dominant.

The disruption in the hierarchy discussed above had a general unstabilizing effect on the flock as a whole. The majority of peck-order violations were noted during the perlod between the flrst reversal of 14 over 1 on January 19 and the w1tnessed reversal of 15 over 1 on January 28. Two days later, 

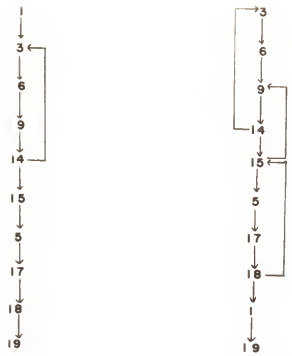

BEFORE REVERSALS

AFTER RE VERSALS

Fig. 3.--Soclograms of Male Flock 24A 
15 suceeded in gaining peck-right over 9. Finally on February 12 , another reversal occurred that resulted in the dominance of 18 over 15 .

TABLE 16

AGGRESSIVE INTERACTIONS IN FLOCK 24A: NUMBER OF OBSERVED PECKSa

\begin{tabular}{|c|c|c|c|c|c|c|c|c|c|c|c|}
\hline \multirow{2}{*}{$\begin{array}{l}\text { Dominant } \\
\text { Cocks }\end{array}$} & \multicolumn{11}{|c|}{ Subordinate Cocks } \\
\hline & 1 & 3 & 6 & 9 & 14 & 15 & 5 & 17 & 18 & 19 & Total \\
\hline 1 & $\because$ & 23 & 18 & 38 & 17 & 20 & 49 & 32 & 10 & 8 & 215 \\
\hline 3 & 17 & . & 15 & 22 & $8 *$ & 37 & 11 & 28 & 20 & 17 & 175 \\
\hline 6 & 10 & - & $\therefore$ & 18 & 24 & 36 & 19 & 31 & 43 & 21 & 202 \\
\hline 9 & रI & $\ddot{0}$ & $\bullet$ & $\because$ & 42 & 13 & 17 & $\overline{3}$ & 18 & 38 & 182 \\
\hline 14 & $\sqrt{43}$ & 47 & 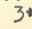 & $10 *$ & . & 31 & $2 *$ & 28 & 48 & 16 & 228 \\
\hline 15 & $\overline{18}$ & $7^{*}$ & $\because$ & 28 & ․ & . & $2 \overline{7}$ & 16 & 17 & 24 & 137 \\
\hline 5 & $\overline{15}$ & • & & $7 *$ & 33 & $\cdots$ & .. & 10 & 9 & 18 & 92 \\
\hline 17 & 10 & . & $6+$ & . & . & 10* & • & . & 7 & 12 & 45 \\
\hline 18 & 4 & . & .. & & . & $\underline{22}$ & .. & .. & $\cdots$ & 32 & 58 \\
\hline & & & & & & 4: & $\cdots$ & ع. & 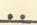 & 1. & 5 \\
\hline
\end{tabular}

anderlining indicates reversals.

*Peck-order violation.

TABLE 17

AGGRESSIVE INTERACTIONS IN FLOCK 24A: NUMBER OF OBSERVED THRFATS*

\begin{tabular}{|c|c|c|c|c|c|c|c|c|c|c|c|}
\hline \multirow{2}{*}{$\begin{array}{l}\text { Dominant } \\
\text { Cocks }\end{array}$} & \multicolumn{11}{|c|}{ Subordinate Cocks } \\
\hline & 1 & 3 & 6 & 9 & 14 & 15 & 5 & 17 & 18 & 19 & Total \\
\hline$\frac{1}{3}$ & $\ddot{i}$ & 12 & 18 & 11 & 10 & 19 & 9 & 8 & 15 & 7 & 109 \\
\hline 3 & 21 & .. & 11 & 5 & ․ & 2 & 12 & 17 & 8 & 11 & 66 \\
\hline 0 & 17 & - & - & 14 & 19 & 4 & 9 & 8 & 12 & 9 & 75 \\
\hline 9 & 24 & $\ddot{0}$ & - & $\cdots$ & 11 & 15 & 18 & 7 & 6 & 14 & 71 \\
\hline 14 & 11 & 19 & . & $\bullet$ & . & 14 & •. & 5 & 9 & 8 & 55 \\
\hline 15 & $\frac{15}{12}$ & $\cdots$ & - & 8 & $\because \dot{x}$ & . & 12 & 9 & 7 & 6 & 42 \\
\hline 27 & $\frac{18}{3}$ & . & - & $\cdots$ & 12 & •. & - & 12 & 8 & 2 & 34 \\
\hline $\begin{array}{l}17 \\
18\end{array}$ & $\frac{23}{12}$ & $\cdots$ & - & $\cdots$ & $\cdots$ & $\because$ & $\bullet$ & - & 5 & 11 & 16 \\
\hline 19 & 15 & $\cdots$ & - & .. & $\cdots$ & $\underline{4}$ & .. & •. & • & 15 & 19 \\
\hline & $\cdots$ & $\cdots$ & $\cdots$ & $\cdots$ & $\cdots$ & ‥ & . & $\ldots$ & .. & .. & 0 \\
\hline
\end{tabular}

*Underlining indicates reversals. 
Some waltzing was observed in this flock but the small number of such occurrences precludes an estimation of 1ts hlerarchal effects. In contrast to flock 3 , a large number of inc1plent mating approaches were witnessed. In these instances the cock seen attempting to mount was always dominant to the contact-mate. Mounting attempts rarely followed a waltz by the dominant. The general procedure was for the mounting individual to approach from behind, grab and/or peck the comb of the subordinate cock while placing one foot on the back or saddle of the latter. These observed attempts were never successful. The subordinate cock was never seen to crouch, but always eluded the dominent. These comments are based on th1rty-three w1tnessed homosexual mating attempts.

Prevention of the crowing of subordinates by dominant members of the organization was erequent, but the larger 11ving quarters in which th1s flock was housed, compared with that of flock 3, enabled low-ranking cocks to crow.

\section{Flock 24B}

A third group of ten adult male Jungle Fowl was assembled for study. Two 1ndividuals, 1 and 19, had been members of the previously discussed flock 24A, and thelr behavior in a sex-segregated group was well known. The remainder had been observed whlle members of heterosexual flocks. The hierarchal behavior of this group was studied from June 23 to October 17, 1953, for a total of 22 hours extending over 81 days. A tabulation of pecks and threats recorded during this interval is 
presented in Tables 18 and 19, respectively. Two soclograms deplcting the social organization appear in Figure 4. A number of peck-order violations were committed by five members of this flock. Also noteworthy were five instances of reversal in dominance, the elrst reversal occurring shortly after study of this group began. Between June 23 and July 2, 94 exercised peck-right over 21 on seventeen occasions. There were no observed peck-order v1olations by 21 against 94 unt1l July 3, when 21 staged a revolt that developed into a fight lasting five minutes. This hard-fought encounter resulted in the submission of 94 , and from that time unt1l study was discontinued 21 was clearly domlnant over 94.

TABLF 18

AGTRESSIVE IUTERACTIONS IN FLOCK 24B: NUMBER OF OBSERVED PECKS ${ }^{a}$

\begin{tabular}{|c|c|c|c|c|c|c|c|c|c|c|c|c|}
\hline \multirow{2}{*}{$\begin{array}{c}\text { Dominant } \\
\text { Cocks }\end{array}$} & \multicolumn{12}{|c|}{ Subordinate Cocks } \\
\hline & 68 & 9 & 21 & & 55 & 24 & 74 & 97 & 19 & 266 & 1 & Total \\
\hline 68 & & 12 & 33 & & 18 & 16 & 38 & 29 & 14 & 38 & 21 & 221 \\
\hline 94 & $\underline{28}$ & & 31 & & 43 & 27 & 45 & 29 & 33 & 28 & 17 & 282 \\
\hline 21 & $\cdots$ & & $\cdots$ & & 34 & 47 & 38 & 17 & 27 & 16 & 33 & 229 \\
\hline $\begin{array}{l}56 \\
24\end{array}$ & . & 1 & •. & & $\because$ & 38 & 18 & 24 & 22 & 18 & 42 & 172 \\
\hline 74 & & . & • & & $26^{*}$ & $\ddot{i B}$ & 58 & 37 & 22 & 17 & 11 & 155 \\
\hline 97 & 2 & . & $\ddot{8}$ & * & 6 & $\frac{20}{4}$ & $\ddot{2}$ & 38 & 30 & 41 & 26 & 179 \\
\hline 19 & • & . & $\because$ & & . & -. & $\ldots$ & $\because$ & 32 & 10 & $\begin{array}{l}17 \\
21\end{array}$ & 95 \\
\hline 266 & $\cdots$ & - & ح & D* & . & $3 *$ & .. & $6 *$ & $\because$ & .. & 13 & 24 \\
\hline & & & & & & & & & . & & & 8 \\
\hline
\end{tabular}

aUderlining indicates reversals. *Peck-order violation. 


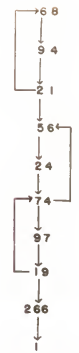

BEFORE REVERSALS

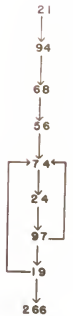

AF TER REVERSALS

Fig. 4.--Soclograms of Male Flock 24B 
TABLE 19

AGGRESSIVE INTERACTIONS IN FLOCK 24B: NUMBER OF OBSERVED THREATS*

\begin{tabular}{|c|c|c|c|c|c|c|c|c|c|c|c|}
\hline \multirow{2}{*}{$\begin{array}{l}\text { Dominant } \\
\text { Cocks }\end{array}$} & \multicolumn{11}{|c|}{ Subordinate Cocks } \\
\hline & 68 & 94 & 21 & 55 & 24 & 74 & 97 & 19 & 256 & 1 & Total \\
\hline 68 & & 18 & 19 & 23 & 14 & $\frac{1}{21}$ & 11 & $\frac{-2}{7}$ & $\frac{5}{5}$ & 29 & $\frac{204}{147}$ \\
\hline 94 & 23 & .. & 12 & 15 & 10 & 7 & 9 & 11 & 8 & 41 & 136 \\
\hline 21 & $\bar{\cdots}$ & 19 & . & 12 & 8 & 4 & 17 & 9 & 3 & 13 & 85 \\
\hline 56 & -. & $\cdots$ & . & .. & 18 & 12 & 9 & 7 & 12 & 18 & 76 \\
\hline 24 & .. & . & .. & & • & $\overline{13}$ & 4 & $\dot{9}$ & 5 & 12 & 43 \\
\hline 74 & . & . & .. & 14 & 8 & .. & 9 & 12 & 6 & 9 & 58 \\
\hline 97 & . & . & . & . & $\therefore$ & $\ldots$ & .. & 10 & 7 & 15 & 32 \\
\hline 19 & . & * & - & . & .. & $\cdots$ & .. & .. & 4 & 11 & 15 \\
\hline 256 & $\cdots$ & . & .. & .. & . & .. & .. & .. & .. & 17 & 17 \\
\hline & & & & & & & & & & & 0 \\
\hline
\end{tabular}

*Underlining Indicates reversals.

Four other reversals occurred, none of which were witnessed. In these instances, the abrupt changes in dominancesubordinance relationships between the individuals involved were quite marked. A tabulation of the reversals appears in Table 20.

\section{TABLE 20}

REVERSALS IN DOMINANCE IN FLOCK 24B

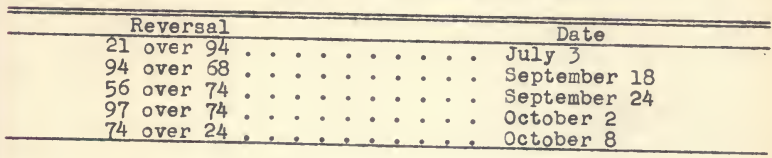

It 1 s of interest to follow the history of 1 , the deposed alpha cock of rlock 24A. After his decline in status, described previously, I became extremely submissive, and 
evaded flockmates constantly. When the present flock was organlzed, 1 was clearly omega and was notably harassed by all. Th1s Indvidual was completely unassimilated into the flock, and the degree to wh1ch flockmates focused agsressive behavior on 1 was demonstrated by the death of this male on September 25. Before the observation period of that date commenced, I was discovered in the pen in the following condition: head and neck completely denuded of feathers, eyes pecked out, and most of the tall feathers missing. The indications are that the deb1litating effects of Inanition and constant avoldance maneuvers allowed some or all flockmates to "gang-up," and the physical alterations observed on 1 are thought to have been made while he was alive.

Waltzing by dominant cocks was not prominently observed. There were few instances of mounting attempts in this group. Prevention by dominants of crowing by low-ranking individuals occurred frequently, but the latter were observed to crow while in the yard.

In summary, close study of three penned flocks of Red Jungle Fowl males reveals the existence of social organization based on peck-r1ght dominance. In the present groups, the structure of the organization as illustrated in soclograms is of the nonlinear type. Contrary to the condition found in flocks of hens, a marked tendency toward Instabllity in dom1nance-subordinance relationships is noted. Some lack of rigid1ty in social status is manlfested by frequent peck-order 
violations and reversals.

A total of twenty complete reversals in dominance is recorded. In addition, a relatively rapld exchanze of dominance between four palrs of cockerels is observed in flock 3 . The recurrent reversals recorded in the cockerel elock may have been a reflection of the relatively small quarters in which this group was housed. Soclal interactions are enhanced under such conditions, and those factors responsible for stablilty of inter-individual relationships, such as rapid recognition of the contact-mate, become strained, with the results noted previously.

The prominent display of waltzing by dominants in the cockerel flock is not readily accounted for. Th1s behavior, although present, was relatively inconspicuous in the two cock flocks. That the age factor was important cannot be entirely dismissed, but it should be recalled that 1 , the despotic alpha individual of the flock was a completely mature adult and his aggressive behavior included the frequent display of waltzing to all subordinates. Another variable was the larger pen and yard that housed the adult groups. Why this increase in space per individual should lead to a marked diminution in waltzing by dominant cocks is not clear and this phenomenon merits further study.

It should be stressed that a bare tabulation of soclal interactions gives an incomplete picture of the dynamics of the hierarchy in these flocks. The disadvantages accruing to 
Low rank can be appreclated only after one watches male flocks in action about the feoding area. Submissive individuals are continuously driven away from the feed. Access to water 18 also difficult for low-ranking males. Although most cocks perch wing to wing at night, a few low-ranking individuals roost alone. Prevention by dominants of the normal vocalizations of subordinate cocks is a further indlcation of the vigorous type of soclal organization displayed by these b1rds. Finaliy, the dysgenic effects induced by the pugnacity of these b1rds is quickly documented by the fact that ten lowranking cocks had elther completely lost vision in one eye, or were apparently blinded as a direct result of fighting. 
SOCIAL ORGANIZATION IN WHITE LEGHORN COCKS

W1th the view of collecting first-hand information that could be used in a zeneral comparison of domestic and Jungle Fowl males, a flock of fifteen white Leghorn roosters, approximately three years old, was assembled. Th1s group, deslgnated flock 2l, was studied at three different intervals. After the first perlod, which extended from November 25, 1952, to March 9, 1953, the Plock was unobserved unt1l July 1, 1953. at which time the number of Individuals was reduced to ten. Th1s group was closely observed from July 1 to october 23, 1953. A third set of records of the same ten cocks was obtalned from April 2 to June 4, 1954. The three sets of data are referred to as $21 \mathrm{~A}, 21 \mathrm{~B}$, and $21 \mathrm{C}$, respectively. Total observation t1me for th1s group was 37.5 hours distributed over 151 days.

Aggressive interactions recorded during the intervals noted above appear in Tables 21 and 22, 23 and 24, and 25 and 26, for flocks 2lA, $21 B$, and 2lC, respectively. A soclogram for each study perlod is presented in Fizure 5. The social hierarchy exhlblted by these groups of White Leghorn cocks is based on peck-right dominance. The structure of the hierarchy devlates from the stralght-line peck-order by virtue of several complexities apparent in the soclograms referred to above. 


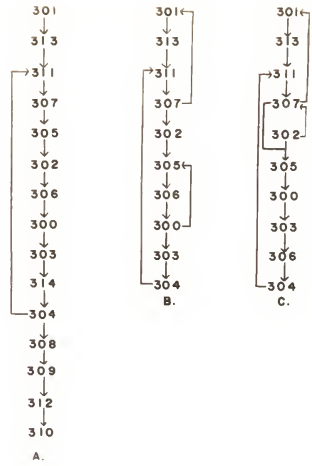

Fig. 5.--3oclograms of White Leghorn male flocks, $21 \mathrm{~A}, 21 \mathrm{~B}$, and $21 \mathrm{C}$. 


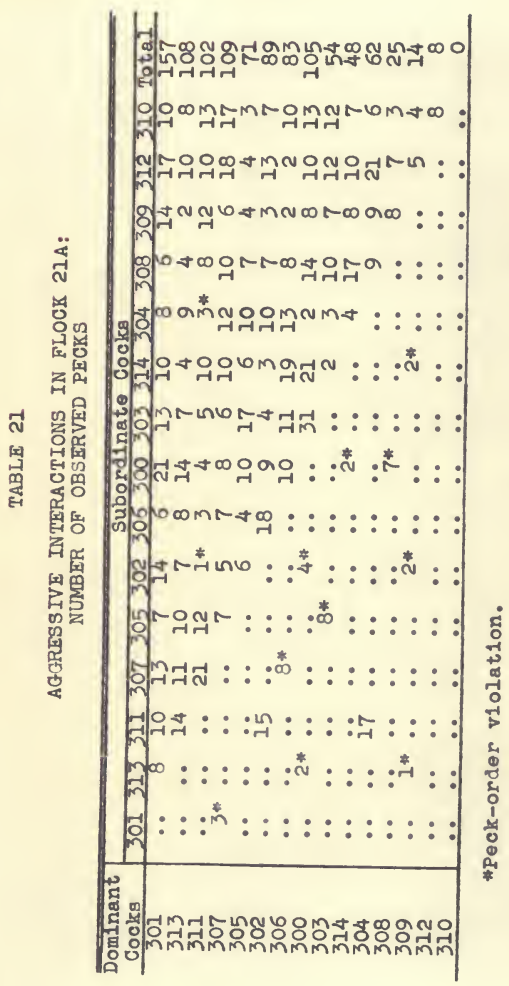




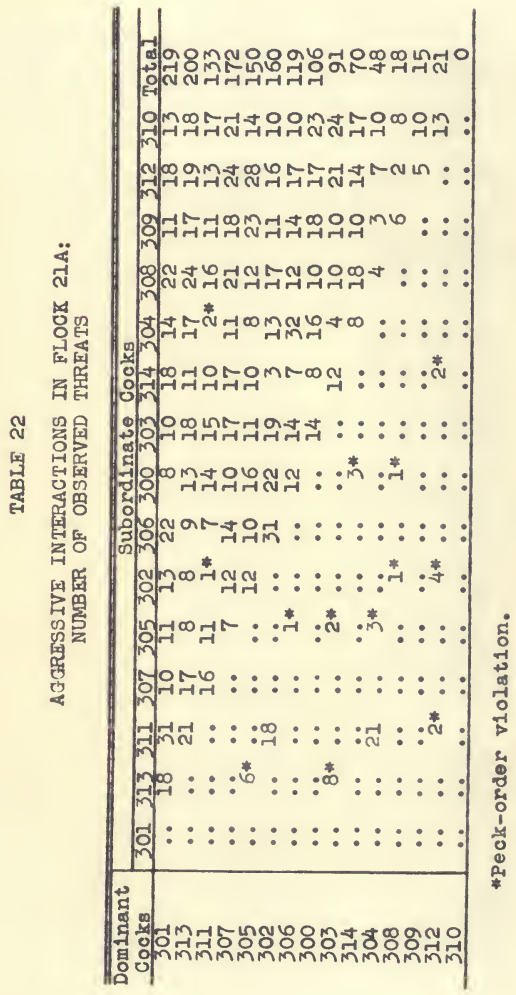


TABLE 23

AGGRESSIVE INTERACTIONS IN FLOCK 2IB: NUMBER OF OBSERVED PECKS

\begin{tabular}{|c|c|c|c|c|c|c|c|c|c|}
\hline \multirow{2}{*}{$\begin{array}{l}\text { Dominant } \\
\text { Cocks }\end{array}$} & \multicolumn{9}{|c|}{ Subordinate Cockg } \\
\hline & 301313311 & 307 & 302 & 305 & 306 & 300 & 303 & 304 & Total \\
\hline 301 & .. 4 & 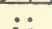 & 6 & 7 & 10 & 13 & 9 & 8 & 62 \\
\hline 313 & .. & 10 & 6 & 7 & 8 & 12 & 14 & 3 & 68 \\
\hline 311 & .. & 13 & 8 & 2 & 10 & 10 & 5 & 2* & 50 \\
\hline 307 & .. & .. & 5 & 9 & 3 & 8 & 10 & 7 & 51 \\
\hline 302 & .. & .. & .. & 4 & 6 & 11 & 10 & 2 & 33 \\
\hline 305 & $2 * \ldots$ & . & .. & .. & 2 & $\therefore$ & 17 & 2 & 23 \\
\hline 306 & .. $\quad$. & I* & .. & .. & . & ii & 5 & 7 & 24 \\
\hline 300 & .. $3 * \ldots$ & .. & .. & 10 & .. & - & $\overline{3}$ & 9 & 25 \\
\hline 303 & - $\quad \cdots$ & .. & .. & .. & .. & .. & .. & 4 & 4 \\
\hline 30 & 12 & & & & & & & 0 & 12 \\
\hline
\end{tabular}

*Peck-order violation.

TABLE 24

AGGRESSIVE INTERACTIONS IN FLOCK 21B: NUMBER OF OBSERVED THREATS

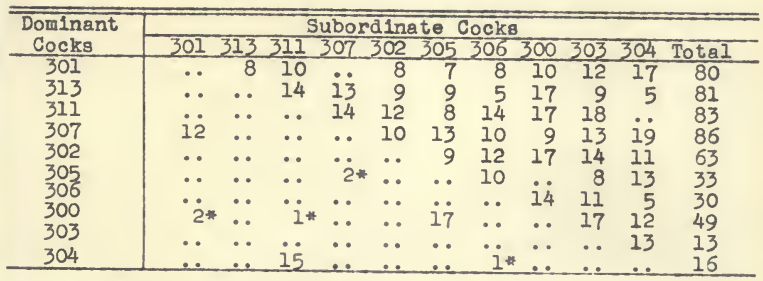

\#Peck-order violation.

As indicated in the tabulations of agsressive interactions, a number of peck-order violations occurred during each of the three periods of study. Nany of these were in the nature of incipient fights that produced no alterations 
in social status. However, four unobserved reversals in dom1nance did take place, two being noted at the Inception of study of flock $21 B$, and two after adequate records of flock $21 \mathrm{C}$ had been collected.

\section{TABLE 25}

AGGRESSIVE INTERACTIONS IN FLOCK 2lC: NUMBER OF OBSERVED PECKS

\begin{tabular}{|c|c|c|c|c|c|c|c|c|c|c|c|}
\hline $\begin{array}{c}\text { Dominant } \\
\text { Cocks }\end{array}$ & \multicolumn{11}{|c|}{ Subordinate Cocks } \\
\hline$\frac{601}{301}$ & $\frac{1}{\cdots}$ & $\frac{212}{14}$ & $\frac{11}{12}$ & 07 & $\frac{302}{13}$ & $\frac{305}{6}$ & $\frac{300}{10}$ & $\frac{303}{13}$ & $\frac{306}{18}$ & $\frac{304}{5}$ & Total \\
\hline 313 & . & . & 21 & 13 & 18 & 12 & 7 & 15 & 9 & $\begin{array}{l}3 \\
7\end{array}$ & 102 \\
\hline 311 & • & . & . & & 5 & 10 & 11 & 17 & 11 & $\bullet$ & 64 \\
\hline 307 & 9 & . & ? & $\because$ & $\cdots$ & 5 & 13 & 5 & 14 & 12 & 58 \\
\hline 302 & •. & $\cdots$ & 1* & 12 & $\cdots$ & 8 & 17 & 10 & 16 & 8 & 72 \\
\hline 305 & •. & $\because$ & . & 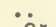 & $\cdots$ & $\cdots$ & 9 & 11 & 7 & 13 & 40 \\
\hline 300 & •. & $1 *$ & $\cdots$ & 2 ฟ & . & -. & . & 10 & 5 & 9 & 27 \\
\hline 303 & - & $\because$ & - & $\cdots$ & . & $\cdots$ & •• & . & 6 & 4 & 10 \\
\hline $\begin{array}{l}306 \\
304\end{array}$ & - & $1 *$ & $i$ & • & 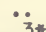 & $\cdots$ & 2* & $\cdots$ & . & 7 & 10 \\
\hline & & & & & & & & & & 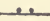 & 15 \\
\hline
\end{tabular}

*Peck-order violation.

TABLE 26

AGGRESSTVE INTERACTIONS IN FLOCK 2IC: NUMBER OF OBSERVED THREATS

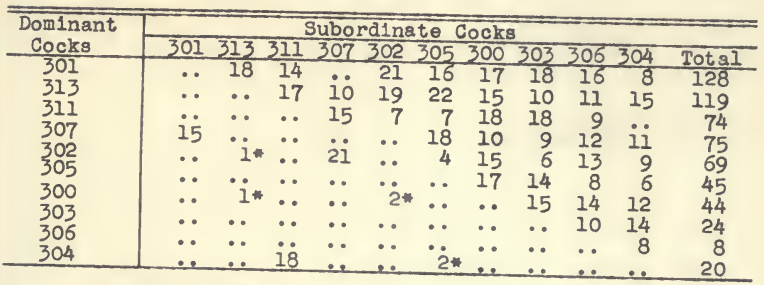

*Peck-order violation. 
Throughout the entire study of this flock of White Leghorns, there was but a single instance of a dominant cock displaying the waltz to a subordinate. Crowling during observation periods was also rare, affording 11ttle opportunity for the assessment of the role of social status in successful vocalization of this type.

Note that the number of threats observed is somewhat greater than that of pecks. The cocks were approximately three years old when first assembled and the less vigorous aggressive display may be a corollary of maturity.

In general we see no marked distinctions between the hierarchal behavior of the Red Jungle Fowl males and that of this small sample of White Leghorn cocks. Both forms show some flexibility with respect to dominance-subordinance relatlonships, and peck-order violations occurred in both. No special emphasis is placed on the larger numbers of these latter phenomena recorded for Jungle Fowl cocks. A report by Masure and Allee (1934) on social order in a flock of eleven Brown Leghorn cockerels presents a picture similar to that provided above, and further substantiates the conviction that no essential difference in hierarchal behavior exists between common domest1c and Jungle Fowl males. 


\section{SOCIAL ORGANIZATION IN HETEROSEXUAL FLOCKS}

OF RED JUNGLE FOWL

In considering observations on heterosexual plocks attention is flrst given to those data that concern hierarchal behavior. A subsequent section deals with reproductive behavlor and includes the presentation of observations that interrelate these two facets of behavior.

\section{Flock 18}

Hierarchal behavior in 1 ts simplest form 1s demonstrated In this group consisting of four males and three females. These individuals were flve and one-half months old when study of the flock was begun on November 14, 1952. Observations were continued unt1l March 24, 1953, for a total of 16.5 hours spread over a 66-day period. A tabulation of pecks and threats recorded during this period appears in Tables 27 and 28, respectively. Sociograms 1llustrating the structures of the social organizations so determined are presented in Figure 6.

Two features are immediately apparent from these data. W1thin th1s small group, two distinct hlersechles are discernible, each including individuals of one sex. The structure of each hierarchy is of the simple, linear type. We note further that although the tendency is for individuals to peck only members of their own sex, some instances of the pecking of b1rds of the opposite sex were recorded. 
56

cocks

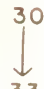

33

$\downarrow$

31

$\downarrow$

32
HENS

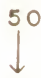

52

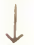

51

F1g. 6.--Soclograms of Heterosexual Flock 18 
TABLE 27

AGGRESSIVE INTERACTIONS IN FLOCK 18: NUMBER OF OBSERVED PECKS

\begin{tabular}{|c|c|c|c|c|c|c|c|c|}
\hline \multirow{2}{*}{$\begin{array}{l}\text { Dominant } \\
\text { Cocks }\end{array}$} & \multicolumn{4}{|c|}{ Subordinate Cocks } & \multicolumn{4}{|c|}{ Subordinate Hens } \\
\hline & 30 & 33 & 31 & 32 & 50 & 52 & 51 & Total \\
\hline 30 & • & 17 & 34 & 21 & $\ldots$ & 3 & 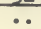 & 75 \\
\hline 33 & .. & . & 33 & 18 & $\bullet$ & . & 2 & 53 \\
\hline 31 & & $2 *$ & $\ldots$ & 19 & $\cdots$ & . & . & 21 \\
\hline 32 & I* & $4 *$ & $2 *$ & e.e & 1 & 2 & 5 & 15 \\
\hline \multicolumn{9}{|l|}{$\begin{array}{l}\text { Dominant } \\
\text { Hens }\end{array}$} \\
\hline $\begin{array}{l}50 \\
52 \\
51\end{array}$ & $\dddot{i}$ & 3 & ․ & $\because$ & $\ddot{2 *}$ & $\begin{array}{l}18 \\
\ldots\end{array}$ & $\begin{array}{l}14 \\
15\end{array}$ & $\begin{array}{r}35 \\
18 \\
0\end{array}$ \\
\hline
\end{tabular}

*Peck-order violation.

TABLE 28

AGGRESSIVE INTERACTIONS IN FLOCK 18: NUMBER OF OBSERVED THREATS

\begin{tabular}{|c|c|c|c|c|c|c|c|c|}
\hline \multirow{2}{*}{$\begin{array}{l}\text { Dominant } \\
\text { Cocks }\end{array}$} & \multicolumn{4}{|c|}{ Subordinate Cocks } & \multicolumn{4}{|c|}{ Subordinato Hens } \\
\hline & 30 & 33 & 31 & 32 & 50 & 52 & 51 & Total \\
\hline 30 & . & 12 & 19 & 22 & . & •• & $\ldots$ & 53 \\
\hline 33 & $\cdots$ & $\cdots$ & 8 & 11 & ․ & .. & $\cdots$ & 19 \\
\hline $\begin{array}{l}31 \\
32\end{array}$ & $\cdots$ & $\cdots$ & • & 7 & . & - & $\cdots$ & 7 \\
\hline \multirow{2}{*}{$\begin{array}{l}\text { Dominant } \\
\text { Hens }\end{array}$} & \multirow[b]{3}{*}{ •. } & \multirow[b]{3}{*}{$\cdots$} & \multirow{4}{*}{ 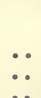 } & \multirow{4}{*}{ 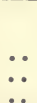 } & \multirow{4}{*}{$\ddot{\bullet}$} & e. & عـ & 0 \\
\hline & & & & & & \multirow{4}{*}{$\begin{array}{l}11 \\
\ldots \\
\ldots\end{array}$} & \multirow{4}{*}{$\begin{array}{l}8 \\
5\end{array}$} & \multirow{4}{*}{$\begin{array}{r}19 \\
5 \\
0\end{array}$} \\
\hline $\begin{array}{l}50 \\
52\end{array}$ & & & & & & & & \\
\hline 51 & $\because$ & $\because$ & & & & & & \\
\hline & & 는 & $\bullet$ & . & . & & & \\
\hline
\end{tabular}

A subjective judgment must at times be made when males peck females, with respect to whether such activity is of a hlerarchal or social nature, or of a sexual or mating nature. Distingulshing criteria to ald the observer in making this distinction are tenuous. For the present those pecks directed by male members of the flock to females are considered as 
hierarchal in nature; this matter is discussed further at a later time. On the other hand, instances in which hens pecked cockerels are considered as expressions of aggressive behavior. Such cases are small in number, and of unknown significance.

A further 1 tem of interest is the fact that aggressive Interactions, pecks and threats, were more frequent between males than between females. Some peck-order violations were w1tnessed in both hierarchies. Desplte these anomolous interactions, no reversals in dominance were noted, except as ind1cated below.

The following series of events are presented because of their interesting consequences. On the evening of March 18, two palrs of b1rds were removed: 30 and 32 , alpha and omega males, respectively, and 50 and 52, alpha and beta hens. These birds were placed in exhibltion cages and were relntroduced 1nto the pen on Narch 22. The b1rds had been absent for a perlod of approximately 48 hours. On relntroduction, 33, beta cock, challenged 30. The resulting flght lasted thirty minutes, at which time 33 had successfully galned a reversal over 30 . The latter was badly beaten, but 33 persisted in raining pecks on the former alphe cock. During the course of this flght, 31 occasionally entered to peck 30 , and It was clear that 31 was now also dominant to 30 . S1x hours later when the flock was again observed, the new alpha cock, 33, was still pursuing 30 about the pen. The following momIng, 30 was discovered dead on the floor, hackle feathers 
missing, comb and wattles mut1lated. Nelther the omega male, 32, nor the reintroduced hens were involved in these disturbances. This was the flrst of a series of observations in which reintroduced birds became disassimilated. At this point, study of the flock was discontinued.

\section{Flook 25}

Study of the hierarchal behavior of thls group began on January 19 and extended to June 9, 1953, for a total of 16.6 hours of close watchlng distributed over 67 days. Tabulations of pecks and threats appear in Tables 29 and 30, respectively, and the social hierarchles so found are deplcted in soclograms presented in Figure 7. The birds comprising this flock were mature adults when assembled. As indicated In the tabulations and soclograms, two separate social organ1 zations are present, each organized into stralght-line dominance hierarchies. Some peck-order violations between males were recorded; none were observed among the hens. One reversal In dominance took place between males 164 and 154, following an extremely hard-fought contest that was initiated by 154. The trigzering circumstances for this, and other apparently spontaneous reversals are not obvious to the observer. Prior to this particular reversal, there were no discemible indications of approaching exchange of dominance. We note again the occurrence of pecks directed by cocks to hens. The behavior of both Individuals in these 


COCKS $\quad$ COCKS

BEFORE REVERSAL AFTERREVERSAL

Fig. 7.--3oclograms of Heterosexual Flock 25 
social interactions differed in no detectable manner from that whlch oocurs when one cock expresses his dominance over a subordinate male. That is, there was no evidence indicative of the preliminary approaches employed by cocks in mating attempts.

One aspect of the hlerarchal behavior mantested in this group was the infrequent observation of aggressive interaction between the hens. This tendency was most prominent during the final month of study, when two consecutive hours of observation revealed no aggressive-submissive behavior. The hens were not in the best physical condition, and 270 , omega hen, dled of pullet disease June 1, 1953.

\section{TABLE 29}

AGGRESSIVE INTERACTIONS IN FLOCK 25: NUMBER OF OBSERVED PECKS ${ }^{a}$

\begin{tabular}{|c|c|c|c|c|c|c|c|c|c|c|}
\hline \multirow{2}{*}{$\begin{array}{l}\text { Dominant } \\
\text { Cocks }\end{array}$} & \multicolumn{5}{|c|}{ Subordinate Cocks } & \multicolumn{5}{|c|}{ Subordinate Hens } \\
\hline & 256 & 244 & 164 & 273 & 154 & 236 & 321 & 210 & 270 & Total \\
\hline $\begin{array}{l}266 \\
244\end{array}$ & $\cdots$ & 28 & 18 & 15 & 19 & 3 & 7 & 4 & 3 & 97 \\
\hline $\begin{array}{l}244 \\
164\end{array}$ & $\cdots$ & - & 31 & 12 & 18 & - & 8 & $\cdots$ & $\cdots$ & 69 \\
\hline 273 & $\because$ & $\ddot{4 *}$ & $\ddot{5}$ & 29 & 14 & $\cdots$ & 5 & 4 & 2 & 52 \\
\hline 154 & & & $18^{5}$ & $\cdots$ & 10 & $\cdots$ & $\cdots$ & - 。 & - & 19 \\
\hline \multirow{3}{*}{\multicolumn{11}{|c|}{$\begin{array}{c}\text { Dominant } \\
\text { Hens }\end{array}$}} \\
\hline & & & & & & & & & & \\
\hline 236 & 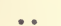 & 0. & & & & & & & & \\
\hline 321 & . & $\because$ & $\cdots$ & $\cdots$ & $\bullet$ & $\cdots$ & 17 & 14 & 23 & 54 \\
\hline 210 & $\because$ & 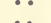 & $\because$ & $\bullet$ & $\cdots$ & $\cdots$ & $\cdots$ & 18 & 4 & 22 \\
\hline 270 & $\therefore$ & $\because$ & $\cdots$ & - & - & . & $\cdots$ & . & 8 & 8 \\
\hline & & & & .. & $\cdots$ & . & $\cdots$ & .. & . & 0 \\
\hline
\end{tabular}


TABLE 30

AGGRESSIVE INTERACTIONS IN FLOCK 25: NUMBER OF OBSERVED THREATS *

\begin{tabular}{|c|c|c|c|c|c|c|c|c|c|c|}
\hline \multirow{2}{*}{$\begin{array}{l}\text { Dominant } \\
\text { Cocks }\end{array}$} & \multicolumn{5}{|c|}{ Subordinate Cocks } & \multicolumn{5}{|c|}{ Subordinate Hens } \\
\hline & 256 & 244 & 164 & 273 & 154 & 236 & 321 & 210 & 270 & Total \\
\hline 266 & $\ldots$ & 38 & 43 & 19 & 17 & $\cdots$ & $\cdots$ & $\ldots$ & $\ldots$ & $\frac{117}{117}$ \\
\hline 244 & . & .. & 28 & 34 & 24 & .. & . & .. & $\ldots$ & 86 \\
\hline 164 & . & . & .. & 19 & 18 & .. & $\cdots$ & . & $\cdots$ & 37 \\
\hline 273 & -. & . & $\ddot{\circ}$ & $\cdots$ & 9 & $\cdots$ & .. & .. & .. & 9 \\
\hline 154 & - & $\cdots$ & 29 & $\cdots$ & - & $\cdots$ & $\cdots$ & - & $\cdots$ & 29 \\
\hline \multicolumn{11}{|l|}{$\begin{array}{c}\text { Dom1nant } \\
\text { Hens }\end{array}$} \\
\hline 236 & • & $\cdots$ & • & $\cdots$ & - & $\cdots$ & 12 & 8 & 14 & 34 \\
\hline 321 & - & $\cdots$ & $\cdots$ & . & $\cdots$ & $\cdots$ & .. & 9 & 10 & 19 \\
\hline $\begin{array}{l}210 \\
270\end{array}$ & $\cdots$ & $\because$ & $\cdots$ & $\cdots$ & $\cdots$ & • & $\cdots$ & $\cdots$ & 5 & 5 \\
\hline & $\bullet$ & $\cdots$ & $\circ 0$ & -. & ‥ & $\cdots$ & $\cdots$ & .. & . & 0 \\
\hline
\end{tabular}

*Underlining indicates reversals.

\section{Flock 23c}

This heterosexual flock was assembled on December 16 , 1953, and was studled unt1l May 18, 1954, for a total of 25 hours of close observation distributed over 101 days. Orlg1nally composed of $s 1 x$ cocks and $s 1 x$ hens, the number of males was reduced during the final three months by the deaths of 244 and 154 of pullet disease.

The social organizations determined for this group are 1llustrated in Figure 8. These hierarchles are based on aggressive interactions that are tabulated and presented in Tables 31 and 32 for pecks and threats, respectively. The two soclal organizations are of the stralght-11ne type with no triangular dominance relationships. This group is marked by the small number of peck-order violations observed between 
cocks

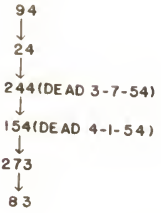

HENS

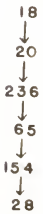

F18. 8.--Sociograms of Heterosexual Flock $23 \mathrm{C}$ 
males. No instances of reversals in dominance were noted. The characteristic stability of the hierarchy among Jungle Fowl hens 18 well documented by this flock. The highlyaggressive alpha hen, 18, continued her despotic behavior first seen when flock $23 \mathrm{~A}$ was under observation, and frequently and persistently pursued subordinate flockmates.

\section{TABLE 31}

AFARESSIVE INTERACTIONS IN FLOCK 23C: NUMBER OF OBSERVED PECKS

\begin{tabular}{|c|c|c|c|c|c|c|}
\hline \multirow{2}{*}{$\begin{array}{l}\text { Dominant } \\
\text { Cocks }\end{array}$} & \multicolumn{2}{|c|}{ Subordinate Cocks } & \multicolumn{4}{|c|}{ Subordinate Hens } \\
\hline & 94242441 & 5427383 & 1820 & $236 \quad 65$ & 15428 & Total \\
\hline 94 & .. 42 51 & $39 \quad 4732$ & $4 \ldots$ & 310 & $\ldots 9$ & 237 \\
\hline 24 & . $\ldots$ & 2917 & & $\bullet$ & 4 & 146 \\
\hline 244 & $\cdots$ & 22185 & 4329 & 1728 & 1119 & 192 \\
\hline 154 & .. 3* .. & 82 & 2 & $1 \ldots$ & ・・ & 17 \\
\hline 273 & . $\ldots \ldots$ & $4 * \ldots 10$ & $\cdots$ & $\cdots \quad \bullet$ & $\ldots$ & 14 \\
\hline$\frac{83}{10 m i n t}$ & $\ldots \ldots$ & $\ldots$ & $\ldots$ & $\ldots \quad 2$ & $1 \ldots$ & 3 \\
\hline $\begin{array}{c}\text { Dominant } \\
\text { Hens }\end{array}$ & & & & & & \\
\hline 18 & $\cdots \cdots$ & • • & .. 27 & 1932 & 2514 & 128 \\
\hline $\begin{array}{r}20 \\
236\end{array}$ & $\cdots \cdots$ & $\cdots \bullet$ & $\cdots \cdots$ & 3115 & 1921 & 86 \\
\hline $\begin{array}{r}236 \\
65\end{array}$ & $\cdots \cdots$ & $\cdots \quad \cdots$ & $\cdots \quad \cdots$ & .. 18 & 413 & 35 \\
\hline 154 & $\cdots \cdots$ & $\cdots \cdot \cdots$ & $\cdots \cdots$ & $\cdots$ & 2 & 9 \\
\hline 28 & $\because \cdots$ & $\because$ & $\because \cdots$ & $\cdots \quad \cdots$ & $\cdots$ & 3 \\
\hline
\end{tabular}

*Peck-order violat1on.

The agsressive behavior directed by male 244 to hens merlts consideration. Th1s cock repeatedly exercised peckright over all hens. There was no indication that these pecks or threats, indicated in Tables 31 and 32, were of a mating nature. It was thought that the behavior of $244 \mathrm{might}$ have some basis in an endocrine abnormality; he was smaller 
than like-aged cocks and had incompletely developed plumage and comb. However, a post-mortem examination revealed that the gross anatomy of the gonads was normal, and as noted above, 244 died of chronic pullet disease.

\section{TABLE 32}

AGGRESSIVE INTERACTIONS IN FLOCK 23C: NUNBER OF OBSERVED THREATS

\begin{tabular}{|c|c|c|c|c|c|c|c|c|}
\hline \multirow{2}{*}{$\begin{array}{l}\text { Dominant } \\
\text { Cocks }\end{array}$} & \multicolumn{4}{|c|}{ Subordinate Cocks } & \multicolumn{2}{|c|}{ Subordinate } & \multicolumn{2}{|l|}{ Hens } \\
\hline & 942 & $24244]$ & 1542738 & 83 & 1820 & $236 \quad 65$ & 15428 & Total \\
\hline 94 & - & 28 & 191 & 12 & . & 3 & $=1$ & 118 \\
\hline 24 & $\cdots$ & 42 & 13 & 2 & $i$ & 2 & $\cdots$ & 81 \\
\hline 244 & $7 *$. & - & 14 & 9 & 10 & . & . 8 & 72 \\
\hline 154 & $3 *$. & $\cdots$ & 71 & 12 & $\cdots$ & .. & & 22 \\
\hline 273 & - & -. & . . I & 10 & . & . & $\because \cdots$ & 10 \\
\hline$\frac{83}{\text { Dominant }}$ & $\ldots$ & $\because$ & $1 * \ldots$ & $\because$ & $\ldots$ & .... & $\ldots$ & 1 \\
\hline Hens & & & & & & & & \\
\hline 18 & $\cdots$ & •. & 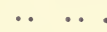 & •. & .. 19 & 922 & 1412 & 76 \\
\hline 236 & $\cdots$ & • & $\cdots$. & •• & •. $\quad \cdots$ & 1018 & 5 & 40 \\
\hline $\begin{array}{r}236 \\
65\end{array}$ & $\cdots$ & • & - & $\cdots$ & - & $\ldots 14$ & 2215 & 51 \\
\hline 154 & $\cdots$ & - & .. & $\cdots$ & . $\cdots$ & $\cdots \quad \cdots$ & 212 & 14 \\
\hline 28 & $\ddot{0}$ & $\cdots$ & $\because$ & $\because$ & $\because \quad \cdots$ & $\cdots$ & .. 9 & 9 \\
\hline
\end{tabular}

*Peck-order violation.

The aggressive attacks by 244 against females in the flock brought retallation by 18 . On one occasion, 18 and 244 assumed fighting postures and began to spar. This development was terminated by the interference of hen 65 who while passing between the posturing birds was vigorously pecked by both. Subsequently, 18 and 244 resumed feeding.

Reference to the tabulations of pecks and threats reveals a larger number of these expressions of aggressive 
behavior exhiblted by cocks. Of the total 870 observed pecks, 609 , or 70 per cent, were delivered by cocks and only 261, or 30 per cent, by hens. Some of this differential may be attributed to the behavior of 244, but the fact that during the final three months of study only four males were present, emphasizes what is thought to be a real difference in hierarchal behavior between the sexes in heterosexual flocks. A similar situation exists when the number of recorded threats is exam1ned. In this instance, the differential 1s 61.5 per cent for males as opposed to 38.5 per cent for females.

With the exceptions noted above, this heterosexual flock presents a typical picture of two separate hierarchies. Males other than 244 were rarely observed in agzressive interactions with hens; only 18 among the latter was noted in aggressive interactions with a male.

\section{Flock 24C}

The presentation of data gathered on the hierarchal behavior of heterosexual flocks closes with a discussion of the present group. Flock 24C, composed of five cocks and $81 \mathrm{x}$ hens, was studied from December 4, 1953, to May 20, 1954, for a total of 24 hours distributed over 96 days. Tabulations of observed pecks and threats appear in Tables 33 and 34 , respectively; soclograms based on these data are 1llustrated in Figure 9.

An outstanding feature of the organizational act1vity displayed by this flock was the instability of dominance- 


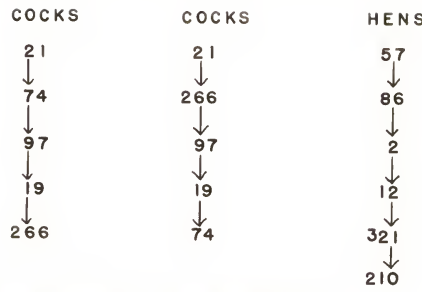

BEFORE REVERSALS AFTER REVERSALS

F1g. 9.--Soclograms of Heterosexual Flock 24C 
subordinance relationshlps that existed among the cocks. Th1s Instablilty was documented by the occurrence of five reversals in dominance.

TABLE 33

AGGRESSIVE INTERACTIONS IN FLOCK 24C: NUMBER OF OBSERVED PECKS Q

\begin{tabular}{|c|c|c|c|c|c|c|c|c|c|c|c|}
\hline \multirow{2}{*}{$\begin{array}{l}\text { Dominant } \\
\text { Cocks }\end{array}$} & \multicolumn{4}{|c|}{ Subordinate Cocks } & \multicolumn{7}{|c|}{ Subordinate Hens } \\
\hline & 21266 & 97 & 19 & 74 & \multicolumn{2}{|c|}{5786} & 2 & \multirow{2}{*}{$\frac{12}{3}$} & 321 & 210 & Total \\
\hline 21 & .. 39 & 28 & 10 & 43 & $\ldots$ & 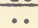 & $\ldots$ & & & & 123 \\
\hline 256 & .. & 18 & 24 & 17 & $\ddot{0}$ & $i$ & $\ddot{0}$ & 2 & & 2 & 64 \\
\hline 97 & & -0 & $\overline{17}$ & टा & & & 3 & . & & 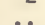 & 49 \\
\hline 19 & 14 & $\ldots$ & $\ldots$ & 19 & 3 & $\dot{2}$ & 8 & i & is & $\ddot{5}$ & 56 \\
\hline 74 & $3 * 9$ & ii & i2 & $\ldots$ & 1 & & & $\frac{1}{2}$ & & & 38 \\
\hline $\begin{array}{c}\text { Dominant } \\
\text { Hens }\end{array}$ & & \multirow[b]{2}{*}{. } & \multirow[b]{2}{*}{.. } & \multirow[b]{2}{*}{. } & \multirow[b]{2}{*}{ - } & \multirow[b]{2}{*}{21} & \multirow[b]{2}{*}{12} & \multirow[b]{2}{*}{23} & \multirow[b]{2}{*}{14} & \multirow[b]{2}{*}{8} & \multirow[b]{2}{*}{78} \\
\hline 57 & $\cdots$ & & & & & & & & & & \\
\hline 86 & •. & . & $\cdots$ & . & - & . & 32 & 19 & 7 & 10 & 68 \\
\hline 2 & . & .. & .. & .. & • & .. & . & 5 & 12 & 9 & 26 \\
\hline 12 & .. & .. & .. & .. & . & . & .. & . & 11 & 4 & 15 \\
\hline 321 & .. & . & . & .. & . & .. & . & .. & $\ldots$ & 7 & 7 \\
\hline 210 & $\ldots$ & $\ldots$ & .. & & & & & & . & 1 & 0 \\
\hline
\end{tabular}

aunderlining Indicates reversals.

*Peck-order violation.

The first reversal occurred under conditions which deserve comment. Prior to the observation of this flock on January 27 , 1t was noted that 74 , the second-ranking cock, had escaped Into the area adjolning the pens. No effort was made to recapture 74 at the time, but that evening he was caught and placed in a nest box outside the pen. The followIng day, 74 was reintroduced at the start of the observation perlod. Shortly after his release 74 was challenged by 97. The ensuing fight in which 74 lost peck-right to 97 and was 
blinded in the left eye was unique in that during 1ts progress all other flock members elther flew to the roost or went out into the yard. Those perched on the roost vocalized throughout the course of the fight in a peculiar manner, and appeared to watch the contesting males.

\section{TABLE 34}

AGGRESSIVE INTERACTIONS IN FLOCK 24C: NUMBER OF OBSERVED THREATS*

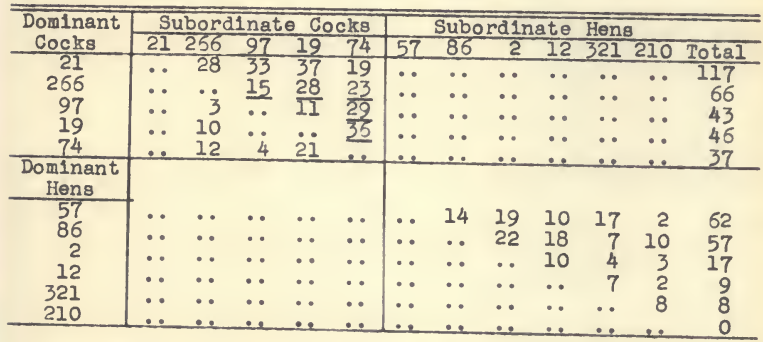

*Underlining indicates reversals.

The following day, January 29, 266 gained a reversal over the battle-scarred 97. This reversal was not witnessed. As Indicated in Table 33, three more reversals occurred, the inal one being recorded on March 3. Tension between the males appeared to diminish after that date; no further reversals were noted.

The hierarchal behavior of the hens in this group was characteristically stable. No reversals or peck-order 
violations were observed. We note again that fewer aggressive interact1ons were witnessed between hens than between cocks. The ratio of pecks and threats recorded in each subgroup for cocks and hens, respectively, was approximately two to one.

In structure, both hlerarchles were of the simple, stralght-line type. Males were rarely observed in aggressive interactions with hens, and the reverse was never witnessed.

\section{Male Mating Behavior}

In addition to the display of hierarchal behavior, some reproductive behavior is observed in heterosexual flocks. Four distinct categorles of male mating activity are clearly discernible. These w1ll be characterized and their occurrence in the present llocks indlcated.

The most frequent type of mating activity exhiblted is the waltz in which the male circles the female with his inner wing lowered, his body inclined toward the female, and his outer wing rapldy eluttered. As noted previously, males in unisexual flocks also display the waltz to subordinates. There is no apparent distinction between a waltz directed by a dominant to a subordinate cock and one directed by a cock to a hen.

Domm and Davis (1948) considered the waltz as a method of sex recognition in domestic fowl; that is, if the bird to which the waltz is directed assumed the sex crouch, the male recognized a mating partner, whereas if the second bird responded by assuming a fighting posture the male then recognized 
another male and an opponent.

On rare occasions, the waltz is followed 1 mmedlately by a peck or an attempt by the cock to grab the comb or the neck feathers of the hen. Because of the confluence of these two activities, they are included as a single pattern in the present anslysis. Pecks delivered by cocks in this context are considered as a part of mating behavior, in contrast to those which are not preceded by a waltz. The latter were presented in the preceding discussion as indications of dominancesubordinance behavior, and in thet context such pecks were not necessarily directed to neck feathers or comb.

A third category of mating behavior is designated mounting attempt. In such instances the male approaches from behlnd, hackle feathers erect, attempts to grasp the comb or the neck feathers of the hen in his beak, and simultaneously extends one foot to the sadale area of the hen's back. Thls procedure was never observed to be preceded by a waltz.

If the hen submits by assuming the sex crouch, copulation or treading follows. This final consummatory act is short-lived and 1s, in turn, followed by dismounting by the cock. The latter generally eluffs his plumage and crows, while the hen stands and fluffs.

With this descriptive material in mind, attention is directed to Table 35 which presents the meting behavior displayed by all males in the heterosexual flocks under discuss1on, plus the records of three cocks intermittently introduced 
TABLE 35

OBSERVED MATING BEHAVIOR OF MALES

IN HETEROSEXUAL FLOCKS

\begin{tabular}{|c|c|c|c|c|c|c|c|c|}
\hline Male & Flock & Rank & 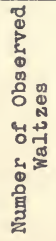 & 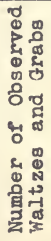 & 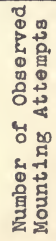 & 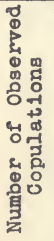 & 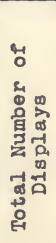 & 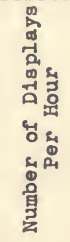 \\
\hline $\begin{array}{l}30 \\
33 \\
31 \\
32\end{array}$ & $\begin{array}{l}18 \\
18 \\
18 \\
18 \\
\end{array}$ & $\begin{array}{l}1 \\
2 \\
3 \\
4 \\
\end{array}$ & $\begin{array}{r}23 \\
13 \\
7 \\
8 \\
\end{array}$ & $\begin{array}{l}2 \\
0 \\
0 \\
0\end{array}$ & $\begin{array}{r}14 \\
11 \\
0 \\
0\end{array}$ & $\begin{array}{l}5 \\
2 \\
0 \\
0\end{array}$ & $\begin{array}{r}44 \\
26 \\
7 \\
8\end{array}$ & $\begin{array}{l}2.70 \\
1.60 \\
0.42 \\
0.48 \\
\end{array}$ \\
\hline $\begin{array}{l}266 \\
244 \\
164 \\
273 \\
154 \\
\end{array}$ & $\begin{array}{l}25 \\
25 \\
25 \\
25 \\
25 \\
\end{array}$ & $\begin{array}{c}\frac{1}{2} \\
3\left(\begin{array}{l}4 \\
4\end{array}\right)^{a} \\
5(4)^{a}\end{array}$ & $\begin{array}{r}12 \\
10 \\
1 \\
5 \\
0\end{array}$ & $\begin{array}{l}0 \\
2 \\
0 \\
0 \\
0\end{array}$ & $\begin{array}{r}10 \\
4 \\
0 \\
0 \\
0\end{array}$ & $\begin{array}{l}0 \\
0 \\
1 \\
0 \\
0\end{array}$ & $\begin{array}{r}22 \\
16 \\
2 \\
5 \\
0\end{array}$ & $\begin{array}{l}1.30 \\
1.00 \\
0.10 \\
0.30 \\
0.00\end{array}$ \\
\hline $\begin{array}{r}94 \\
24 \\
244 \\
154 \\
273 \\
83 \\
\end{array}$ & $\begin{array}{l}23 \mathrm{C} \\
23 \mathrm{C} \\
23 \mathrm{C} \\
23 \mathrm{C} \\
23 \mathrm{C} \\
23 \mathrm{C}\end{array}$ & $\begin{array}{l}1 \\
2 \\
3 b \\
4 b \\
5 \\
6\end{array}$ & $\begin{array}{r}45 \\
21 \\
3 \\
12 \\
8 \\
0\end{array}$ & $\begin{array}{l}3 \\
0 \\
0 \\
0 \\
0 \\
0\end{array}$ & $\begin{array}{r}21 \\
13 \\
10 \\
0 \\
0 \\
0\end{array}$ & $\begin{array}{l}7 \\
2 \\
0 \\
0 \\
0 \\
0\end{array}$ & $\begin{array}{r}76 \\
36 \\
13 \\
12 \\
8 \\
0\end{array}$ & $\begin{array}{l}3.00 \\
1.40 \\
0.72 \\
0.60 \\
0.30 \\
0.00\end{array}$ \\
\hline $\begin{array}{r}21 \\
266 \\
97 \\
19 \\
74\end{array}$ & $\begin{array}{l}24 C \\
24 C \\
24 C \\
24 C \\
24 C\end{array}$ & $\begin{array}{c}5\left(\frac{1}{3}\right)^{a} \\
2\left(\frac{4}{5}\right)^{a}\end{array}$ & $\begin{array}{r}38 \\
14 \\
9 \\
5 \\
0 \\
\end{array}$ & $\begin{array}{l}4 \\
0 \\
0 \\
0 \\
0\end{array}$ & $\begin{array}{r}43 \\
19 \\
0 \\
0 \\
0\end{array}$ & $\begin{array}{l}8 \\
2 \\
3 \\
2 \\
0\end{array}$ & $\begin{array}{r}93 \\
35 \\
12 \\
7 \\
0\end{array}$ & $\begin{array}{l}3.90 \\
1.50 \\
0.50 \\
0.30 \\
0.00\end{array}$ \\
\hline $\begin{array}{r}106 \\
62 \\
23 \\
\end{array}$ & $\begin{array}{l}10 \\
10 \\
10 \\
\end{array}$ & $\begin{array}{l}1 \\
2 \\
3 \\
\end{array}$ & $\begin{array}{r}27 \\
11 \\
0 \\
\end{array}$ & $\begin{array}{r}10 \\
0 \\
0 \\
\end{array}$ & $\begin{array}{r}49 \\
0 \\
0 \\
\end{array}$ & $\begin{array}{r}15 \\
2 \\
0 \\
\end{array}$ & $\begin{array}{r}101 \\
13 \\
0\end{array}$ & $\begin{array}{r}10.10 \\
1.30 \\
0.00 \\
\end{array}$ \\
\hline \multicolumn{3}{|c|}{ Totals } & 272 & 21 & 194 & 49 & 536 & \\
\hline
\end{tabular}

$a_{\text {Rank after reversals. }}$

${ }^{b}$ Died during observation interval. 
1nto Plock 10. These latter individuals were admitted into flock 10 on every Friday evening between December 5, 1953, and March 21, 1954. They were allowed to remain in the pen until Sunday evening, at which time they were removed and placed in the unobserved surplus pen. While in flock 10, the dominance-subordinance positions of these cocks were noted, and their mating behavior closely observed for perlods of 20 minutes on each Saturday and Sunday. The data tabulated for these individuals were collected during 10 hours of observation, distributed over 30 days.

Returning to an examination of Table 35, we note several factors that merit discussion. of the four categories of behavior included, waltzing contributed the largest portion to the total, followed by mounting attempts, copulations, and waltz and grab instances, in that order. Only on two occasions was a waltz followed by copulation. The remaining 47 cases of copulation followed mounting attempts. The waltz and grab sequence was never observed as a successful preliminary to treading.

Heterosexual flocks were under close observation for 92.1 hours. During this time, a total of 536 instances of mating activity of all types were recorded, or an averaze of approximately six per hour. It is entirely possible that Plocks undergoing observation did not display as much mating behavior as occurred in the absence of the observer. However, utilizing the avallable data it is our contention that low- 
ranking males rarely succeeded in mating, at any time.

That there is an association between high rank and the display of mating behavior is indicated by the fact that the alpha and beta cocks in the various flocks contributed 462 , or 86 per cent, of the combined total of 536 mating maneuvers. Contrariw1se, the various omega cocks displayed mating behavior on only elght occasions.

A correlation coefflelent $(r)$ was calculated to determine the extent of association between social status and mating behavior. The total number of observed mating activities per hour for each cock was tested with the number of individuals each male was dominant over.

Table 36 presents a summary of this analysis. In all flocks $r$ is extremely high, indicating a positive assoclation between the two variables tested. The analysis was carried further with a teat to determine the statistical probability of the calculated $r$. The null hypothesis is that $r$ is equal to zero (Snedecor, 1945). Does the $r$ of each flock differ to such a degree that the null hypothesis is rejected? In flocks 25, 24C, and 23C, composed of flve, flve, and six males, respectively, $\boldsymbol{r}$ is found to be significant at the 5, 5, and less than 1 per cent levels of confldence, respectlvely. However, the $r$ values for nelther flock 18 nor 10 passed the test for significance. In the former case, the probability of obtaining an $r$ as high as +0.94 is 5 to 10 out of 100 cases on the basis of chance alone. For flock 10, this probability is 20 
to 30 out of 100 cases on a chance bas1s. In other words, these two values for $r$ could have been the result of sampling error, with the few individuals involved.

\section{TABLE 36}

CORRELATION BETWEEN RANK AND DISPLAY

OF NATING BEHAVIOR IN MALES

\begin{tabular}{l|l|c|c|c|c}
\hline Flock & N & $\begin{array}{c}\text { Hours } \\
\text { Observed }\end{array}$ & $\begin{array}{c}\text { Mat1ng } \\
\text { React1ons } \\
\text { Per Hour }\end{array}$ & $\begin{array}{c}\text { Correlation } \\
\text { Coefflc1ent } \\
(\boldsymbol{r})\end{array}$ & $\mathbf{P}$ \\
\hline 18 & 4 & 16.5 & 5.20 & 0.94 & 0.10 to 0.05 \\
25 & 5 & 16.6 & 2.70 & 0.90 & 0.05 \\
$23 \mathrm{C}$ & 6 & 25.0 & 6.02 & 0.93 & $<0.01$ \\
$24 \mathrm{C}$ & 5 & 24.0 & 6.20 & 0.90 & 0.05 \\
10 & 3 & 10.0 & 11.40 & 0.93 & 0.30 to 0.20 \\
\hline
\end{tabular}

However, the likelihood of obtalning five very high values for $r$ in five consecutive trials seems remote, and despite the lack of statistical signiflcance in two of the flocks, we are convinced of the validity of these findings. A scatter dlagram for each flock, with a trend line calculated by the method of least squares appears in Figures 10 and 11 . These data suggested a simple experimental procedure that would serve to increase our confidence in the preceding observations. To this end, a male flock, sex-segregated for approximately $81 x$ months and consisting of $81 x$ cocks, was selected as a test group. The straight-line dominance hierarchy of the flock from alpha to omega was: $21,97,273,287,74$, and 101. 


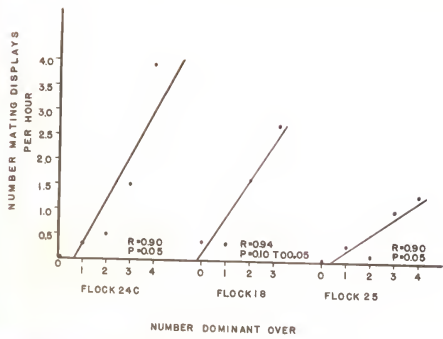

F1g. 10.--Scatter diagrams of malo mating behavior In llocks $24 \mathrm{C}, 18$, and 25. 


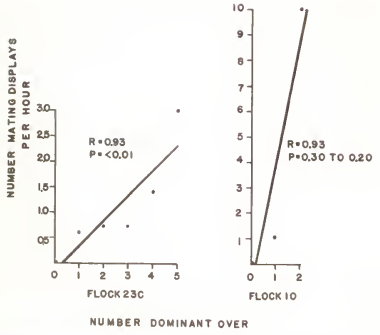

Fiz. 11.--Scatter diagrams of male mating behavior In flocks $23 \mathrm{C}$ and 10. 
The procedure was as follows. A hen from a female flock was removed from its pen the evening preceding the test, and placed in a trap nest. Prior to beginning the test the following moming, all cocks were lured out of the pen by placing srains in a central area of the yard. The door to the pen was locked and the hen placed in the yard. Observations of mating behavior were collected for 20 minutes. In addition to the four categories of male mating behavior described in the preceding section, a flfth pattem consisting of pursult of the hen by a male appeared under these test conditions.

Observations were recorded during three test periods, with an interval of one week between each test. These data are presented in Table 37. Seventy-f1ve of the 81 instances of mating displays of all categorles, or 92 per cent, were contributed by 21, the alphe cock.

TABLE 37

TEST OF MALF MATING BEHAVIOR: NUMBER OF MATING DISPLAYS WHEN ALL COCKS ARE PRESENT

\begin{tabular}{c|c|c|c}
\hline \multirow{2}{*}{ Cock } & \multicolumn{3}{|c|}{ Number of Mat1ng D1splays } \\
\cline { 2 - 4 } & Flrst Trial & Second Trial & Third Tr1al \\
\hline 21 & 19 & 32 & 24 \\
97 & 0 & 0 & 0 \\
273 & 0 & 0 & 0 \\
287 & 5 & 0 & 0 \\
74 & 0 & 0 & 0 \\
101 & 1 & 0 & 0 \\
\hline
\end{tabular}

A fourth test was mun in which 21 was locked inside the pen for ten minutes after the hen had been released. Tallies of the mating displays of the five remalning cocks 
were made during this ten-minute interval, after which 21 was released. Observation of the now complete flock was continued for another ten-minute period. The resulting tallies appear in Table 38. Twenty-six instances of mating behavior were recorded prior to the release of 21. All but two of these were executed by 97 , the beta cock. After his release, 21 contributed all of the 20 instances of mating activity recorded during the final ten-minute phase of the test.

TABLE 38

TEST OF MALE MATING BEHAVIOR: NUMBER OF MATING

DISPLAYS IN THE ABSENCE AND PRESENCE OF 21

\begin{tabular}{c|c|c}
\hline \multirow{2}{*}{ Cock } & \multicolumn{2}{|c}{ Number of Mat1ng Displays } \\
\cline { 2 - 3 } & Firgt Ten Mimutes & Final Ten M1mutes \\
\hline 21 & Absent & 20 \\
97 & 24 & 0 \\
273 & 0 & 0 \\
287 & 1 & 0 \\
74 & 1 & 0 \\
101 & 0 & 0 \\
\hline
\end{tabular}

A fifth trial carried the experiment one step further with the exclusion of both 21 and 97 from the yard at the outset of the test. Ten minutes after observation of the flock commenced, 97 was released. Following a further interval of ten minutes, 21 was released. Table 39 presents these data, and we note that during the first ten-minute phase, twelve of the thirteen mating displays were comm1tted by 273, gamma cock; during the second ten-minute phase the hen was monopolized by 97, beta cock. Mating activity during the final ten-minute 
phase was dominated by 21 .

TABLE 39

TEST OF MALE MATING BEHAVIOR: NUMBER OF MATING DISPLAYS IN THE ABSENCE AND PRESENCE OF 21 AND 97

\begin{tabular}{r|c|c|c|}
\hline \multirow{2}{*}{ Cock } & \multicolumn{3}{|c}{ Number of Matins Displays } \\
\cline { 2 - 4 } & F1rst Ten Minutes & Second Ten Minutes & Finsl Ten Minutes \\
\hline 21 & Absent & Absent & 18 \\
97 & Absent & 19 & 0 \\
273 & 12 & 0 & 0 \\
287 & 1 & 0 & 0 \\
74 & 0 & 0 & 0 \\
101 & 0 & 0 & 0 \\
\hline
\end{tabular}

A final test was made after the hierarchy of the flock had been experimentally readjusted. The alpha cock, 21, was removed and placed in isolation for five days. When relntroduced, 21 was engaged by 97 in a hard-fought contest that rosulted in the reversal of 97 over 21. The remaining members of the flock except 101 also engaged 21, while the group was under observation. Subsequent study indicated that 21 had lost status to $97,273,287$, and 74 .

Two days following these reversals, a final test was run, the results of which appear in Table 40. All cocks were present in the jard when the hen was released. Twenty-five instances of mating behavior were witnessed, all but two executed by 97, the new alpha cock. The former top-ranking male, 21, did not display mating behavior, and, indeed, kept completely out of the area of activity. 


\section{TABLE 40}

TEST OF MALE MATING BEHAVIOR AFTER DEPOSITION OF 21

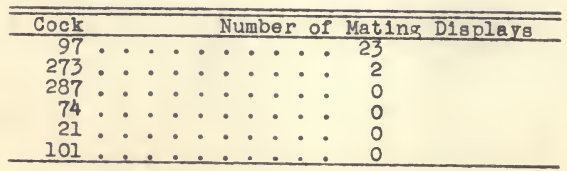

There can be no doubt that under the conditions of these tests, there is a marked tendency for high-ranking and very l1ttle tendency for low-ranking males to display mating behavior.

\section{Female Mating Behavior}

Among hens in heterosexual flocks of Red Jungle Fowl the exhibition of mating behavior is less varied than among cocks. In general, females show three types of response to mating advances by males. The most frequent response is one of avoldance. This ranges from moving a step or two away from the male, to rapid evasion. A second response is acceptance and copulation. The final type of reaction is an apparent complete disregard of the male.

It is of interest to recast the data presented in the preceding section to determine if a relationship exists between rank in the female hierarchy and the number of mating displays directed to a given hen. These data are presented in the form of scatter diagrams in Figures 12 and 13. 


\section{2}

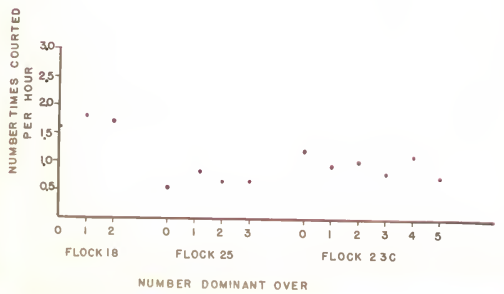

F1z. 12.--Scatter diagrams of female mating behavior in flocks 18,25 , and 230 . 


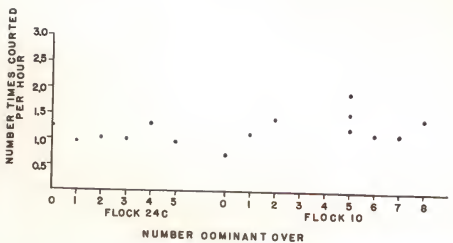

Fig. 13.--Scatter diagrams of female mating behavior in flocks $24 \mathrm{C}$ and 10. 
There is no discernible association between rank or number of Individuals dominated and the number of mating displays directed to a given hen. Low-ranking hens are as apt to recelve mating advances as are high-ranking hens.

It $1 \mathrm{~s}$ pertinent to note again the small number of mating reactions recorded with respect to the total amount of time during which this behavior was observed. That a substantial amount of reproductive activity occurred unwitnessed is polnted up by the appearance of a patch of skin denuded of feathers behind the comb of all hens. Th1s area was particularly visible from early to late spring, and was the result of mating activity by males.

Although eggs were lald throughout the year, the most successful period for reproduction in this colony was from February to July. A clutch of five to elght eggs was deposited on the pen floors or in the yards. When eggs were laid in the pen, incubation proceeded with difflculty only in those cases in which two hens were in production at the same time. There was a tendency for the dominant hen of such a palr to gather as many of the eggs as possible under her. This procedure resulted in the somewhat ludicrous c1rcumstance of two broodIng hens, huddled wing to wing, with all the eggs under one. After hatching, mortality of chlcks developing from eggs lald in the pens was high. Although extremely protective, brooding hens were not able to prevent flockmates, male or female, from killing and eating the newly-hatched chlcks. 
For this reason, chicks hatched in the pens were remored and brooded artificlally.

Those eggs lald in the yards fared somewhat better. However, chicks hatched from these eggs rarely lived to adulthood. They were subject to pecking by all adults except the broody hen when they entered the pen for feed.

\section{Summary of Soc1al Organization and Mating Behavior \\ in Heterosexual Flocks}

Heterosexual flocks of the Red Jungle Fowl exhibit two distinct hierarchies, each inclualng individuals of one sex. W1th the exception of cock 244, males rarely reacted to females in an agzressive manner. In some instances, it 1s difflcult to determine whether a peck by a cock is an incomplete mating attempt or a reflection of aggressive behar1or. Hens peck males infrequently, but our data are of insufflolent quantity to elaborate on this phenomenon.

Structurally, each organization varies, as it does In unisexual flocks. The hen organizations are quite stable with few peck-order violations and no reversals; cock hiorarchies show instability in the form of peck-order violations and reversals. In all flocks, the number of observed agsressive interactions tends to be greater between cocks than between hens. The causal factorg involved in this differential are not clear. Males were never observed to interfere actively in aggressive interactions between hens. 
The study of heterosexual flocks included the recordIng of mating behavior. Although only 49 cases of copulation were witnessed, the occurrence of other manifestations of mating allowed an opportunity for an analysis that revealed the following information. There is a high degree of assoc1ation between social status in the male hierarchy and the exhibition of mating displays. Correlation coefficlents calculated on the basis of number of mating displays of all kinds and number of cocks dominated, indicate a high correlation in all flocks. However, in two flocks, because of the small number of cocks, the coefficlents were found to be insigniflcant, and could very well have been due to sampling error.

A serles of tests using a sex-segregated cock flock reinforced our conviction that males of high status are more active sexually.

Among hens, there is no apparent assoclation between status and the number of times a given Individual is courted. This held true even in those instances in which copulation followed courting.

The rearing of chlcks hatched in the pens and yards was not successful. In order to maintaln the colony, it was necessary to remove newly-hatched chlcks and brood them art1ficlally, since chlcks left in the pens were generally pecked and killed by the adult residents. 


\section{STAGED INITIAL ENCOUNTERS BETWEEN HENS}

A serles of pair-contests was conducted between hens that had no previous experience with each other. Th1s procedure simulates the conditions that are present in assembling a flock when a number of Individuals are placed together for the first time. However, the pair-contest situation is very much simplified in that only two hens are present in a pen unfamiliar to both. Approximately thlrty contests were conducted, but the dismupting effects on the general behavior of the hens as a result of handling in daylight forced a discontinuation of the project.

In view of the small number of experiments it is felt that a detailed analysis of the results would not be reward1ng. Some 1mpressions w1ll be presented, w1th the understandIng that they are not based on extensive data.

When placed together in an unfamillar pen, two hens engage in a contest for dominance. During these initial encounters, one of the following conditions may pertaln: (1) peckright is actively established by plghting initlated by one or both individuals simultaneously; (2) peck-right is passively assumed by the avoldance of one hen by the other without an exchange of pecks or in the complete absence of physical contact; (3) no decision is reached during the period of time arbitrarily chosen for each contest. 
When juvenile hens of four to six months were palred w1th adults, they 1nvarlably lost peck-right to the older hen. The most vigorous azgressive display by a hen was the waltzand-grab sequence, previously described as a manifestation of male mating behavior. Postural differences were noted, but a complete serles of postures as observed by Foreman and Allee (1954) for domest1c hens in pair-contest experiments was not witnessed.

These preliminary observations indicate that an extensive serles of pair-contests would be a worthwhile project not only with respect to Red Jungle Fowl hen behavior, but from a comparative point of view. There is presently avallable a considerable amount of data pertaining to pair-contests in the common domest1c hen.

Because of the pugnacity of males, palr-contest experiments are not recommended. A few were conducted in the present study, but 1t was clear that too often cocks w1ll fight unt1l one is dead. 


\section{TERRITOR IALITY}

As defined by Allee et al, (1949), "Territorlality includes homing or the defense of a given area, or both." Nice (1941) has characterized a number of different types of terr1torlality exhiblted by various species of birds. An attempt was made to determine whether any phenomena which could be designated as territorial behavior exist in our subspecies of Red Jungle Fowl.

We have noted that displays of mating behavior in heterosexual flocks are most frequent during the spring. In addition, no indications of palr-formation were obtained in these flocks. It was thought that the restricted areas in which the flocks were maintained, combined with the relatively large number of individuals in each flock might serve to eliminate palr-formation.

A large jard, measuring roughly $50 \times 22$ feet, was used In four tests to determine the presence or absence of pairformation and territorial defense of portions of the yard. Three nesting sites consisting of wooden boxes located about 20 feet apart were placed in the yard; each site was provided with a water container. A rank growth of weeds prevented visual contact at the level of the Jungle Fowl's head between the three nesting sites, and a centrally-located blind for the observer afforded a clear view of all three nests. All tests 
were conducted during the spring months of 1953 and 1954.

\section{Test 1}

Three pairs of adults, selected from unisexual flocks, were released in the yard on April 5, 1953. The group was observed for periods of twenty minutes dally unt1l May 10. Prior to the start of observation periods, grains were placed In front of each nest box.

The most frequent type of behavior exhlbited was hierarchal in nature. Mating displays differed in no respect from that observed in the previously described heterosexual flocks.

On April 14, the beta cock executed a reversal over the alpha male. From that time until study of the group ended, the deposed male was observed with the others only at night. All birds roosted together on top of one of the nest boxes. On April 14, the alphe hen became broody, laying elght eggs in as many days. Shortly thereafter, the two remaining hens likewise produced clutches of egss. These were deposited In shallow depressions on the ground, and were well hidden by grasses. After hatching, the chicks were protected by their respective dams, and cocks were not seen in close proximity to any of the brooding hens. Each hen kept apart from the other females, and based on size differences of the chlcks from each clutch, no mixing of offspring occurred.

\section{Test 2}

On March 29, 1954, two pairs of seven-month-old b1rds 
were placed in wire cages each located at opposite ends of the yard. The nest boxes used in the preceding test were removed. The birds were caged for three weeks, feed and water belng supplled dally.

On April 18, at 5 a.m., the cages were opened and observations taken. Two and one-half hours after release, both palrs had moved out of the1r respective cazes and wandered about the yard. During this interval of moving, the cocks crowed cont1nuously. In these random movements, the hens did not accompany cocks with which they had been caged.

Four hours after release, dominance relations between blrds of each sex became established; a short flght occurred between the cocks, whereas peck-right was settled by the avoldance of one hen by the other.

The following morning, after graing were placed in front of each cage, It was noted that a male from the pen adjolning the experimental yard had gained entry. The test, so dismupted, was discontinued.

\section{Test 3}

Two different pairs of adults were used in the third test, one pair being caged at each end of the yard for three weeks. After belng released at 5 a.m. on Mry 16, 1954, dom1nance relationships were promptly established. Four hours after release, both hens were observed to accompany the alpha cock about the yard. The beaten male stayed out of contact 
w1th the others. Observations were continued for ten days during which time mating behavior between the alpha cock and both hens was witnessed. The omega male jolned the others only at night when all roosted together.

\section{Test 4}

The final test followed the patterm of the preceding two. Two palrs of blrds were caged for three weeks. Early in this interval, one hen la1d a clutch of six egge and began to incubate them. The cock w1th whlch she was kept soon showed evidence of broodinz behavior, and flve days after the egss were lald cock and hen sat wing to wing with all the eggs under the former. Th1s curlous behavior was unique in that no other instances of a brooding male were encountered. The cages were opened at 5 a.m. on July 18, 1954, after a three-week perlod, and throughout thelr first day of freedom both palrs remeined within five feet of their respective cages. The day after release inftial encounters occurred and dominance relations became established, w1th the formerlybroody cock assuming alpha status. All blrds moved about the yard together. Hierarchal and mating behavior were witnessed, but these phenomena were in no way distinct from those occurring in large heterosexual flocks. One week after release, the omega cock was found dead, apparently as the result of f1ghting with the alpha cock. 
In summary, the release of pairs of Red Jungle Fowl Into a large jard resulted in the exhibltion of hlerarchal and mating behavior similar to that witnessed in larger heterosexual flocks. Blrds whlch had been caged for three weeks prior to release did not appear to maintain a territory about their respect1ve cages. The highly aggressive behavior shown by alpha cocks resulted in the death of one omeza male, and the exclusion of two different omega cocks from contact with other b1rds in the yard. The fact that all b1rds roosted together at nlght although during the daylight one cock might be excluded from association with his yardmates is further evidence for a lack of territorial behavior. No indications of pair-formation were noted in any of the tests. 


\section{DISCUSSION}

Small flocks of Red Jungle Fowl hens clearly exhiblt a social organization based on the peck-right type of dom1nance-subordinance relationship between members of the group. Dominance is manifested by overt behavioral activity such as pecking and threatening. The structure of the social organizations found in the four flocks under discussion ranges from the simple, straight-line hierarchy in flock 23B to the rather complicated geometrical-type of organization of flock lOB.

The rigldity of dominance relationships among flock members is amply 1llustrated by the data presented above. A combined total of 9,279 pecks and threats were recorded during 78.3 hours of observation, extending from July 1953 to November 1954. Of this totel, there were only fifteen instances In which an observed aggressive act ran counter to the known dominance-subordinance relationshlps of the hens. The role of such peck-order violations in the dynamics of hierarchal behavior is incompletely understood (Holabird, 1955). These phenomena may indicate conditions of stress preliminary to actual reversal in dominance between members of the contact pair, but there is no evidence from the present study that such is the case. On the other hand, such behavior may simply reflect the rapid movements that are characteristic of the feeding hens. 
Misdirected aggressive activity under these circumstances seems entirely likely; the rareness of such behavior is mute testimony of the ablilty of Jungle Fowl hens to recoznize their flockmates precisely and rapidly, and to react appropriately in the vast majority of contacts.

The stability of dominance-subordinance relationships in this form is further indicated by the behavior of those hens which were members of two flocks. With one exception, such individuals maintained the same relationship to each othor in both flocks.

The expression of submissive behavior by the subordinate of a pair-contact has not been emphasized. The response of subordinate individuals to peciling or threatening by soclally dominant flockmates is such as to increase the distance between the dominant and the interacting subordinate. The latter may move her head away from the dominant, or may run or fly out of the feeding area. The form of the avolding response was of particular interest only in those cases in which subordinate hens exhibited the sex crouch to an overt aggressive act by hen 18, alpha member of flocks $23 \mathrm{~A}$ and $23 \mathrm{~B}$. Under these conditions, the sex crouch is an unadaptive response. A hen in this attitude may remain motionless while being pecked repeatedly by the dominant. The sex crouch so displayed may be an example of a displacement activity. As generally defined by Thorpe (1951) a displacement activ1ty is, "The performance of a behaviour pattern out of the particular functional context of behaviour to which it is normally related." 
The sex crouch may be considered as a typlcal response given by a sexually receptive hen when pecked by a cock approaching from behind. After the first sex crouch was noted in flock $23 \mathrm{~A}$, care was exercised to observe the manner of approach of hen 18 when interacting with subordinates. Recall that 18 was a particularly azgressive individual, and that she frequently chased subordinates for some time before returning to the feeding area. It 1s interesting to note that four of the five cases of sex crouch response to 18 occurred when the latter was in pursult of the subordinate individual and was thus approaching vigorously from behind, as would a male attempting to mount. The small number of these observations, however, demands cautious interpretat1on. Pursuit by dominants did not invariably, or even frequently, evoke the sex crouch by the subordinate individual.

It would be of interest, at this point, to compare the hierarchal behavior of Red Jungle Fowl hens with that of common domestic hens. Beginning with the published works of Schjelderup-Ebbe (1913, 1922, 1935), and extending through the investigations of Allee and his students, a rather considerable body of information concerning social organization In common domestic fowl is avallable. The reviews of Allee (1950) and Guhl (1953) represent the latest summarles of this fleld, and the reader is directed to these papers for documentation of many of the comparative statements to follow. 
There is no essential difference between the type of social organization exhlbited by small flocks of the two forms. In both, the hierarchy is based on peck-right dominance. Soclal relationships between individuals are determined during initial pair-contacts and are of an enduring nature. The structure of the hierarchy varies from the simple stralght-Iine type to the complex geometrical peck-order in which complicated dominance relationships are encountered.

The manner in which dominance is exerclsed is the same In both Red Jungle Fowl and common domestic hens. Pecking and threatening are the primary manifestations of dominance behav1or. Fighting rarely occurs in organlzed flocks of domest10 hens. It was never encountered in the present study. The activity of subordinate members of interacting pairs is similar, and varles from slizht avoldance movements to rapld evasion of the dominant.

In a study designed to test the ability of domestic hens to become part-t1me members of a number of flocks, Douglis (1948) noted that dominance relations of test hens did not change when the hens were moved from one flock to another even though one member of the pair may have attalned higher status In a given flock than did lts transfer partner. This finding is paralleled, with the single exception noted previously, by the behavior of those hens that were members of two flocks in the present study. 
In a zeneral way, the social organization found in small, penned flocks of Red Jungle Fowl males 19 similar to that of hens. Dominance is of the peck-right type and the hierarchies range in complexity from the simple, stralghtline type found in the male flock used for tests of mating behavior, to the highly complicated structures present in flock 3. However, hlerarchal behavior of males differs from that of females in the relative lack of stability manifested in dominance-subordinance relationships. Peck-order violations are frequent in male flocks, and complete reversals in dominance relationships common.

Competition for high rank in the male hierarchy is extreme. F1ghts developinz for reasons not apparent to the observer frequently result in permanent bodily infury or even in the death of a defeated cock.

The most striking example of the highly competitive nature of the male hierarchy is the history of 1 , alpha cock of llock 3. When a member of this group, 1 was an aggressive despot, exercisinz peck-right over all subordinates in a persistently harsssing manner. During the first two months of study, I was also alpha in the organlzation of flock $24 \mathrm{~A}$. Abruptly, 1 lost status in a series of reversals to all but the omega male. Following these reversals, I was virtually an outcast, being continuously driven about the pen and yard. St1ll later, when a member of flock 24B, I continued in a subordinate status, and finally succumbed to persistent attacks 
by dominant members of the flock.

Dominance was demonstrated not only by pecking and by threatening behavior, but also by the tendency of dominant males to prevent crowing by subordinate cocks. It is difficult to concelve of crowing as an agrressive challenge in the conditions under which the male flocks were studied. At best, crowling by subordinates might be considered as an extremely cryptic challenge, particularly when a dominant was in close proximity. In such c1rcumstances, the slightest threat by the dominant was usually a sufficlent stimulus to curtail the vocalization.

Waltzing by dominants of subordinate individuals was noted in all flocks, but was most prominent in flock 3 . Infrequently, attempts at homosexual mating were witnessed in all male groups except flock 3 . In these instances, the cock attempting to mount was always higher in the social organization than the interacting male. Successful mounting was never observed, and subordinate males were never seen in the sex crouch position assumed by receptive hens.

The unlque behavior observed in flock 3 has been discussed. The reasons for recurrent reversals and very frequent waltzing displays are not clear. More work is suggested on closely confined groups of cockerels.

Schjeldemup-Ebbe (1922) characterlzed the hlerarchal behavior of domest1c cocks as similar to that of domestic hens, with an additional comment concerning the tendency for cocks 
to show a wilder type of behavior. Masure and Allee (1934) studied the social organization in a flock of eleven Brown Leghorn cockerels. They found the hlerarchy to be less stable than that exhibited by a similar group of pullets. Dominance relationships between two pairs of cockerels were unsettled after a period of 70 days, and flve cases of revergals in dominance were noted. The hlerarchy was constructed of a serles of triangles of dominance. No mention is made of waltzing and crowing in this report.

Guhl (1953) states that the organization in unisexual Plocks of domest1c males is similar to that of hens, except that interactions between cocks are more intenge and dominance relationsh1ps less stable.

These reports agree with the observations presented above on a flock of flfteen and later of ten White Leghorn roosters. Reversals in dominance as well as peck-order violat1ons were encountered in this group. These indications of a less rigid form of dominance-subordinance organization are similarly apparent in the hierarchles exh1bited by Red Jungle Fowl cocks. We conclude that no essent1al difference ex1sts in the exhibition of hierarchal behavior of males of the two forms under conslderation.

The hlerarchy in heterosexual flocks of Red Jungle Fowl consists of two separate, sex-11mited organizations. The hierarchal behavior manifested by each sex-grouping is completeIy compatible with that found in the respective unisexual 
flocks. That is, status among hens is rigidly maintained with few peck-order violations and no reversals, whereas among cocks both indications of instability are common.

For the most part, cocks exert dominance over hens in a covert manner. Some instances of overt aggressive behavior directed to hens by males are encountered. One cock (244), abnormal in appearance, frequently exercised peck-right over all hens in his flock. The degree to which this exceptional behavior was displayed stands in contrast to the zeneral comportment of males, noted above. Cocks clearly have precedence in feeding; it is curious indeed that such precedence is generally unaccompanied by repeated displays of azsressive behav1or.

Cases wherein hens exhib1t aggressive behavior to cocks are also exceptional. Only 18, a highly aggressive hen, was observed pecking males to any degree. This female was also involved in inciplent pighting maneuvers with 244, the cock referred to above.

One other aspect of the hierarchal behavior recorded in heterosexual flocks is the differential in aggressive activity. In every case, hens were observed in fewer interactions than males. The causal factors involved in this differential expression of agsressive behavior are unknown. It is clear, however, that hens are in some manner inhiblted in the display of aggressiveness by the mere presence of males. Cocks were never seen to interfere actively in aggressive 
interactions among hens.

The assemblage of heterosexual flocks allowed the collection of data concerning mating behavior. Male displays include waltzing, waltzing and grabbing, mounting attempts, and copulation. Female exhibition of mating behavior is confined to the sex crouch. Other responses of hens to displaying cocks are in the nature of avoldance reactions or apparent complete disregard of the male.

Plotting comblned number of mating displays per hour against number of cocks dominated revealed a high degree of association between these two quantitative variates. Correlation coefflclents for all flocks were very hizh, but in two cases the observations coula have been the result of sampling error with the small numbers of males involved. Testing a unlsexual flock of $81 x$ cocks for frequency of mating displays to an introduced hen, reinforced the conclusion draw from observational data collected on heterosexual flocks. High rank in the male hierarchy was closely associated with the frequency of mating displays.

When these data were recast, and the frequency with which a given hen was courted was plotted against number of hens dominated, no association was revealed. Low-ranking hens were courted and trod as frequently as their social dominants.

The information concerming hierarchal behavior in heterosexual flocks of the common domestic fowl indicate two 
separate hierarchles. Passive dominance of males over females is the rule, with rare exceptions. Instances of hens pecking cocks have also been observed, but these too are exceptional cases.

Most reports dealing with heterosexual flocks of domestic fowl are concerned with the relationship between hierarchal and mating behavior. These papers have been reviewed recently by Allee (1950) and Guhl (1953). It w1ll be pertinent here to summarize those findings bearing on a comparison of domestic with Red Jungle Fowl behavior.

With respect to male mating behavior, it has been establlshed that, in heterosexual flocks, high-ranking cocks tread more frequently and tend to sire more offepring than lowranking males. Dominant cocks also tend to interfere in the mating efforts of their soclal subordinates. However, when Introduced singly in hen flocks, the sexual vigor of individual males in no way reflects their social status.

Among domestic hens, the reverse situation obtains. Low-ranking hens are courted more frequently than those of higher social status. The correlation between status in the hlerarchy and frequency of copulation is also negative.

The observations of the present study indicate no differences in the relationsh1p of mating display with soclal status between Red Jungle Fowl and domest1c cocks. A very marked distinction appears on the female side, however. No 
relationship between status and frequency of belng courted is observed in Red Jungle Fowl hens, whereas a negative correlation between these two varlables is found in domestic hens. The same distinction appears with respect to copulation in the two forms.

It may be that the small number of forty-nine witnessed copulations in the present study afford too small a sample for the detection of differential mating in hens. Consideration of the combined data of mating displays indicates the same trend, however, and we are faced w1th a considerable difference. The act of copulation in both forms clearly involves a large factor of submissiveness on the part of the hen. The only objective criterion of apparent receptivity in hens is assumption of the sex crouch. We have noted that some Jungle Fowl hens will assume the sex crouch when pursued by a highly aggressive hen. Thls phenomenon is also known to occur in unlsexual flocks of domestic hens.

There is no positive evidence that the males of a heterosexual flock are cognlzant of the soclal status of a given hen. There 18 thus no a priori reason for suspecting that cocks will display mating behavior more frequently to low than to high-ranking hens. In the absence of palr-formation for breeding purposes, we might assume that a given male will display mating behavior in a nonselective manner. That low-ranking domestic hens copulate more frequently than their social dominants is understandable if the mating pattern is 
largely based on submissiveness. The curious point is that domestic hens low in the hierarchy not only engage in copulation more frequently than dominant ones, but also that the former are courted more frequently.

This observational fact, to be logically interpreted, demands the assumption that a male is in some manner aware of the relative submissiveness of each hen in his flock.

In a long-established heterosexual flock, it is quite likely that, on the basis of experience, a cock may recognize a differential in agsressiveness among hens. That is, some hens w1ll assume the sex crouch more frequently than others. There are also postural differences between aggressive and submissive hens (Foreman and Allee, 1954) that could provide the necessary cues to males. It follows that the male might court such hens more frequently than their more agsressive flockmates. If this should occur, the explanation for a differential in frequency of being courted is then the result of the ability of males to detect, on the basis of long experience, or on the basis of subtle postural cues, differences in submissiveness of hens. Submissive behavior in hens is normally associated with low rank in the hierarchy. We may conclude that cojnizence of low-ranking hens, as such, by cocks is quite indirect but effective in domestic boterosexual flocks.

The findings in the present study with respect to Jungle Fowl hens do not parallel those of domestic hens. There 
Is no reason to suspect that Red Jungle Fowl cocks are less percept1ve of submissiveness in hens than domest1c cocks. If the preceding argument is cogent, we should expect a differential in frequency of being courted, associated with rank in the female hierarchy. It is concelvable that the alstinction rests on an actual difference between domestic and Red Jungle cocks, such that, in the latter, courting without regard to relative submissiveness of hens is an indication of higher sexual vitality in this form. Further experimental invest1gation of this problem would be a worthy venture.

Delacour (1951) reports that Cochin-Chinese Red Jungle Fowl ( . g. jallus) have been kept in a park located in clères, Normandy. Under these conditions the blras are sald to behave in a manner indistinguishable from wild birds in Indo-China. During summer, autumn, and winter, these freeranging Jungle Fowl 11ved in small, mixed flocks. However, each spring,". . each of the stronger cocks keeps a territory with three to flve hens." The dimensions of these terr1torles are not given.

We have noted that maintenance of a territory and palr-formation did not occur in our heterosexual flocks. In tests conducted in a yard approximately $50 \times 22$ feet in length and width, there were no obvious indications of defense of a portion of the yard, or of pair-formation.

A different interpretation may be placed on the results of these tests if the entire yard be considered. In 
all except the second test, which was discontinued because of the intrusion of a nonexperimental male, there was evidence Indicating that alpha cocks exerted control over the yard. That 1s, they moved about preely and were seen displaying and mating with the hens. In test 3 , the subordinate male was never observed with the two hens and alpha cock during the day. Test 4 gave the same indications, with flghting between males so extreme that the omega cock was k1lled. Test 1 was less conclusive because of the onset of egs production and broodiness in the hens. The winning of alpha status by the orlginally second-ranking cock was accompanled by the withdrawal of the former alpha male from the others. The omega cock of test $I$ was seen in contact with hens and with the alpha male, although he was never observed in mating attempts.

Had low-ranking males been able to escape from the yard, the alpha cocks might then have been in the same position as the "stronger" cocks mentioned by Delacour.

The most obvious fault in this interpretation is the fact that all birds roosted together at night. Delacour makes no statements about roosting behavior but it seems safe to assume that a second cock would not be found roosting with the territory-holding male and his harem.

Repetition of these experiments using a larger area would test this interpretation, and pending such an investigation we feel that no generalizations should be drawn from the present study on territoriality. 
There are approximately 45 standard breeds of domest1c fowl (Am. Poultry Assoc., 1953). Each breed may, In turn, be. divided into a number of varleties. The varleties are frequently further divided into strains. It is obvious that domestic fowl have undergone intense selection by poultry breeders for centuries. Among the many factors which have been under selection are color patterns, feather form, body size and conformation, meat and egs production, and broodiness. It is therefore of interest that in those breeds, varieties, and stralns which have been studied, no basic differences in the manifestation of hierarchal behavior have been found. There are varlations between breeds and between strains of a single breed variety with respect to levels of asgressiveness and other minor character1stics (Potter, 1949; Holab1rd, 1955), but it is noteworthy that despite long and intense artificial selection for other factors, few important differences in the expression of hierarchal behavior are known among flocks of I. gallus.

In concluding this part of the discussion it may be sald that no basic distinction is found between the social orzanization of flocks of Red Jungle Fowl and of the common domestic fowl. Indeed, Insofar as its hierarchal behavior is concerned, the Red Jungle Fowl does not differ from the common domestic fowl to any greater degree than certain breeds of domestic fowl are known to differ from each other. 
The fact that soc1al organization in the Red Jungle Fowl is basically indistinguishable from that of the closelyrelated domestic fowl is an indication of the fundamental nature of this behavioral phenomenon. Collias and Taber (1951) noted a social hlerarchy based on peck-right dominance in free-ranging ring-necked pheasant hens (Phasianus colchicus) another specles of the family Phaslanidae in which both Red Jungle Fowl and domestic fowl are classified.

Such a widespread and persistent behavioral character1stic as social hierarchy is not without evolutionarg significance. An evaluation of tinis problem differs on the individual and the group levels and a discussion of each is pertinent. Competition within a flock for high soclal rank is extreme. We have seen that manifestations of aggressive behavior are more vigorous among males than among females and that the resulting organizations are more stable in the latter than in the former. This distinction may simply reflect the larger size of males and presumably larger titres of male hormone in the blood. The effectiveness of exogenous male hormone in increasing aggressiveness in domestic hens is well known (Allee, Collias, and Lutherman, 1939; Allee and Foreman, 1955).

The experimentally-demonstrated perquisites of high rank in flocks of domestlc fowl are also well known. Among cocks, high soclal status is assoclated with greater realization of reproductive potential, as well as greater access to foed, water, and other essentials of Individual survival. 
Should such a system occur in nature, selection might favor the most aggressive males. This is certainly the case among males of free-ranging sage grouse (Centrocercus urophasianus), as reported by J. W. Scott (1941, 1942).

The situation among hens is less clear, for we have seen that, in domestic fowl, females of high rank may not fully realize their reproductive capab1lities. There is no doubt that high-ranking individuals in both domestic and Red Jungle Fowl Plocks are in an advantageous position with respect to individual malntenance.

The disoperative consequences of interindividual competition are obvious. If selection were to favor extreme aggressiveness in both male and female, a point of diminishing return would eventually be reached because the reproductive act, as such, requires a certain degree of submission by the hen. The complex of motor activitles whlch we have designated as aggressive behavior is presumably genetically determined, although aspects of learning are certainly involved in 1 ts operation. It may well be that the tendency for low-ranking domestic hens to be more active in reproduction results in a balancing mechanism that serves to prevent a genetic overemphasis of those factors which make for aggressiveness.

A more basic consideration is presented when attention is shifted to the group as the unit of selection. Here the 1mportant question is whether flocks in which the social hierarchy is well-established are in an advantageous state relative 
to unorganized groups. There is a paucity of experimental evidence on this basic question. Some insight is provided by the report of Guhl and Allee (1944) in which such factors as egs production, welght maintenance, and levels of aggressive activity of white Leghorn hens were studied. The hens were members of two subsamples of a single population, one of which consisted of organized, control flocks, and the other of flocks undergoing constant reorganization. They found the following relationships: hens in flocks undergolng reorganization showed a higher frequency of agsressive activity, consumed legs feed, and tended to produce fewer egzs than those in control flocks. The conclusion of this study was that soclal organization,". . may serve to bulld a co-operative soclal unit better fitted to compete or co-operate with other flocks at the group level than are soclally unorganized groups." It is our contention that a similar experiment using the Red Jungle Forl would show the same trend if the tests were made during the spring period of highegt egg production.

A practical application of the basic information disclosed by investigations dealing with social behavior in the domest1c fowl has been the recent advent of oaged-layer operations in the poultry industry. Within the past four years approximately one million individual cages for laying hens have been installed in Florida alone, representing a total investment of over three million dollars. One of the primary 
reasons for this type of management is that birds in individual cages are not subject to the disoperative effects of the social hierarchy. Each individual has equal access to food and water with a resulting high level of egs production. The elimination of interindividual competition leads to a more complete realization of zenetic potentialities for egs production as well as more efficlent utilization of feed.

It should be emphasized that this study was conducted under conditions which were somewhat restrictive to the birds. It would be of interest to know the nature of the hierarchal behavior shown by Red Jungle Fowl in thelr natural environment. Descriptions of the natural history of the Red Jungle Fowl, such as that of Beebe (1926) and Delacour (1951) are not helpful in this respect. However, a recent report by Tordoff (1954) on the social organization of the red crossbill provides some insight into the present problem. A flock of this passerine species was observed in the field and 1ts hierarchal behavior was noted. After trapplnz, the flock was observed under restricted conditions, and it was concluded that the onIy noticeable change was an increase in display of aggressivesubmissive activity.

Social organization is a factor exerting a dynamic influence on the total blology of certain grouped anlmals. An appreciation of the significance of these intricate and subtle intercelationships can prove a potent instrument for a more complete understanding of group blology. 


\section{SUMMARY}

1. The social organization of twenty-six Red Jungle Fowl hens comprising four flocks was studied for a combined total of 78.3 hours extending from July 7,1953 , to November 23, 1954.

2. A social hierarchy based on peck-right dominance relationships was found in each flock; only one case of reversal of dominance was encountered.

3. Other evidence of stability of social status stemmed from the unchanged dominance-subordinance relations between hens that were members of two flocks.

4. There was some association of higher social status with long-time residence in a given pen when the hens were regrouped.

5. Comparison with the well-known hierarchal behavior of the closely-related common domestic hen revealed no basic differences in the manifestation of social organization. 6. The social organization of Red Jungle Fowl males, assembled in three flocks of thirteen, ten, and ten individuals, respectively, was studied for a combined total of 79.7 hours, extending from February 18, 1952, to October 17, 1953.

7. A social hierarchy based on peck-right dominance relationships was found in each flock. 
8. Hierarchal behavior of the male differed from that of the female in the relative lack of stability of dominancesubordinance relationships in the former.

9. Peck-order violations were frequent; twenty complete reversals in dominance were recorded in the male flocks.

10. In addition to pecks and threats, dominance was reflected in the active interference with the crowing of subora1nate cocks by their social dominants.

11. Waltzing was a prominent aspect of aggressive behavior in male flock 3 composed of one cock and twelve cockerels, but was infrequently witnessed in adult male sroups.

12. Study of the hierarchal behavior of White Leghorn males in conjunction with information in the literature revealed no essential distinction between the Red Jungle and domest1c cocks with respect to their soc1al organization.

13. Fifteen hens and sixteen cocks assembled in four heterosexual flocks of Red Jungle Fowl were studied for 82.2 hours between November 4, 1952, and May 20, 1954.

14. The hlerarchy in heterosexual flocks conslsted of two separate, sex-limited organizations.

15. Males rarely directed aggressive behavior to hens; the reverse was also infrequently witnessed.

16. There was a tendency for females to exhibit less aggressive behavior than males in heterosexual flocks.

17. A positive correlation between high rank in the hierarchy and frequency of mating displays by males was noted. 
18. There was no assoclation between status in the femele organization and the frequency with which a given hen was courted.

19. The hierarchal behavior of heterosexual flocks of the common domestic fowl was essentially simllar to that found in the Red Jungle Fowl.

20. A distinction between the common domestic and Red Jungle Fowl was found with respect to female mating behavior; there is a negative correlation between rank and frequency of being courted in domestic hens, whereas no correlation between these two factors was discernible in the present study of Red Jungle hens.

21. Four tests to determine the extent of territoriality in the subspecies studied revealed a tendency for alpha cocks to exert control over the enclosed area used for the study. However, 1t was suggested that no generalization be drawn from these data because of the relatively small area used and the fact that subordinate males could not actually be driven out of the yard.

22. A series of thirty staged initial palr-contests between females was conducted. The results of these encounters and the behavior manifested by the contesting jungle hens paralleled that shown by common domestic hens. The adverse effects of handling the birds in daylight forced a discontinuation of the contest series. 
23. This report adds to our knowledge of the soclal organization exhiblted by a previously unstudied group. Compar1son of the hlerarchal behavior of penned flocks of Red Jungle Fowl and the closely-related common domest1c fowl revealed no essential distinctions. 
APPENDIX

SUMMARY OF FLOCK ORGANIZATION AND STUDY PERIODS

\begin{tabular}{|c|c|c|c|c|c|}
\hline Flock & \begin{tabular}{l|} 
Flock \\
Type
\end{tabular} & $\begin{array}{l}\text { No. Hours } \\
\text { Observed }\end{array}$ & $\begin{array}{l}\text { No. Days } \\
\text { Observed } \\
\end{array}$ & $\begin{array}{c}\text { Inclus 1ve } \\
\text { Dates of Study }\end{array}$ & Flock Membership \\
\hline$\overline{10 A}$ & 98 & 21.0 & 74 & \begin{tabular}{|rrr} 
Nov, 24, & 1953 \\
to & \\
March 22, & 1954 \\
\end{tabular} & $\begin{array}{l}30,196,47,160, \\
189,156,29 *, 130 \\
34 *\end{array}$ \\
\hline$\overline{10 B}$ & 90 & 18.0 & 107 & $\begin{array}{|ccc|}\text { June } 14, & 1954 \\
\text { to } & \\
\text { Nov. } 19, & 1954 \\
\end{array}$ & $\begin{array}{l}22,196,322,160, \\
57,12,210,130, \\
106,189\end{array}$ \\
\hline $23 \mathrm{~A}$ & क्ष & 21.2 & 65 & $\begin{array}{l}\text { Aug. 9, } 1953 \\
\text { to } \\
\text { Nov. 2, } 1953\end{array}$ & $\begin{array}{l}18,20,57,86,2, \\
12,210,17,321\end{array}$ \\
\hline$\overline{23 B}$ & $\% 0$ & 18.1 & 109 & $\begin{array}{r}\text { June 15, } 1954 \\
\text { to } \\
\text { Nov. 23, } 1954\end{array}$ & $\begin{array}{l}18 *, 20,66,154, \\
86,158,17,40 * \\
47,38\end{array}$ \\
\hline 3 & 88 & 31.7 & 127 & $\begin{array}{r}\text { Feb. 18, } 1952 \\
\text { to } \\
\text { Aug. } 12,1952 \\
\end{array}$ & $\begin{array}{l}1,2,5,3,12,4,8 \\
6,9,7,10,11,13\end{array}$ \\
\hline $24 \mathrm{~A}$ & 80 & 26.0 & 89 & \begin{tabular}{|r|r|} 
Nov. 13,1952 \\
to \\
March 20, 1953 \\
\end{tabular} & $\begin{array}{l}1,3,6,9,14,15 \\
5,17,18,19\end{array}$ \\
\hline $24 \bar{B}$ & 80 & 22.0 & 81 & $\begin{array}{r}\text { June } 23,1953 \\
\text { to } \\
\text { oct. } 17,1953 \\
\end{array}$ & $\begin{array}{l}68,94,21,56,24 \\
74,97,19,266,1\end{array}$ \\
\hline $\begin{array}{l}21 \mathrm{~A} * * \\
21 B * * \\
21 \mathrm{C} * *\end{array}$ & 80 & 37.5 & 151 & $\begin{array}{l}\text { Nov. } 25,1952 \\
\text { to } \\
\text { June } 4,1954\end{array}$ & $\begin{array}{l}301,313,311,307, \\
305,302,306,300, \\
303,314,304,308, \\
309,312,310\end{array}$ \\
\hline$\overline{18}$ & $\delta 9$ & 16.5 & 66 & \begin{tabular}{|r|r|} 
Nov. 14, 1952 \\
to \\
March 24, 1953 \\
\end{tabular} & $\begin{array}{l}30,33,31,32,50, \\
52,51\end{array}$ \\
\hline$\overline{25}$ & 80 & 16.6 & 67 & \begin{tabular}{|} 
Jan. 19, 1953 \\
to \\
June 9, 1953
\end{tabular} & $\begin{array}{l}266,244,164,273, \\
154,236,321,210 \\
270 *\end{array}$ \\
\hline 23C & $\delta 8$ & 25.0 & 101 & $\begin{array}{l}\text { Dec. 16, } 1953 \\
\text { to } \\
\text { May 18, } 1954\end{array}$ & $\begin{array}{l}94,24,244^{*}, 154^{*}, \\
273,83,18,20,236, \\
65,154,28\end{array}$ \\
\hline $24 \mathrm{C}$ & 89 & 24.0 & 96 & $\begin{array}{l}\text { Dec. } 4,1953 \\
\text { to } \\
\text { May 20, } 1954\end{array}$ & $\begin{array}{l}21,256,97,19,74, \\
57,86,2,12,321, \\
210\end{array}$ \\
\hline
\end{tabular}

*Died during study period.

* Wh1te Leghom male flocks. 


\section{LITERATURE CITED}

Allee, W. C. 1950. Dominance and hierarchy in societies of vertebrates. Colloques Internationaux du Centre Nat1onal de la Recherche Scient1f1que. XXXIV. Structure et phys1ologie des soclétés animals. Plerre P. Grassé, Ed., pp. 157-181.

, Coll1as, N. E., and Lutherman, C. Z. 1939. Modif1cations of the social order in flocks of hens by the injection of testosterone proplonate. Phys1ol. Zool., 12:412440.

1949. Emerson, A. E., Park, O., Park, T., and Schmidt, K. P.

, and Foreman, D. 1955. Effects of an androgen on dom1nance and subordinance in $81 x$ common breeds of Gallus gallus L. Physiol. Zool., (In press).

American Poultry Association. 1953. The Amerlcan standard of perfection. Davenport, Iowa: American Poultry Assoclation.

Banks, E. M., and Allee, W. C. 1954. Effects of flock $81 z e$ on agsressive behavior in domest1c hens. Anat. Rec., 120 (3): $734-735$.

Beebe, W. 1926. Pheasants: the1r 11ves and homes. Vol. I. Garden Clty, New York: Doubleday, Page and Co.

Coll1as, N. E. 1943. Stat1st1cal analys1s of factors which make for success in initial encounters between hens. Amer.
Nat., $77: 519-538$.

, 1944. Aggressive behavior among vertebrate animals. Phys 101. Zool., 17(1):83-123.

, and Taber, R. D. 1951. A fleld study of some grouping and dominance relat1ons in ring-necked pheasants. Condor,

Crane, J. 1949. Comparat1ve b1ology of salt1c1d sp1ders at Rancho Grande, Venezuela. Pt. III. Systemat1cs and behav1or in representative new spec1es. Zoolog1ca, 34(2): 31-52. 
Dawin, C. 1868. The variation of an1mals and plants under domest1cation. London: J. Murray.

Delacour, J. 1951. The pheasants of the world. New York: Charles Scribners Sons.

Domm, L. V., and Dav1s, D. E. 1948. The sexual behav1or of Intersexual domest1c fowl. Phys10l. Zool., 21(1):14-31.

Dougl1s, M. B. 1948. Soclal factorg 1nfluenclng the hlerarchies of small Plocks of the domest1c hen: interactions between resident and part-time members of organized flocks. Phys1ol. Zool., $21(2): 147-182$.

Emerson, A. E. 1938. Termite nests -- a study of the phylogeny of behavior. Ecol. Monogr., 8:247-284.

Foreman, D., and Allee, W. C. 1954. A correlation between posture stances and outcome in palred contests of domest1c hens. Bull. Ecol. Soc. Amer., 35(3):68.

Guhl, A. M. 1953. Soc1al behavior of the domestic fowl. Tech. Buil., 73. Agric. Exp. Stat., Kansas State College.

, and Allee, W. C. 1944. Some measurable effects of social organization in flocks of hens.' Phys101. Zool., 17(3):320347.

Helnroth, 0. 1910. Beltr"̈ge zur B10log1e, inbesonders Psychologle und Ethologle der Anatiden. Verh. V. Int. Ornithol. Kongr.

Holab1rd, C. 1955. Soc1al organtzation in flocks of Light Brahma hens with comparisons to other breeds. Physiol. Zool., (In press).

Hutt, F. B. 1949. Genet1ce of the fowl. New York: MoGraw-H1ll.

Lorenz, K. Z. 1950. The comparative method in studying innate behaviour patterns. Symposia of Soclety for Experimental Blology IV. (221-268). New York: Academic Press.

Masure, R., and Allee, W. C. 1934. The soc1al order in flocks of the common ch1cken and p1geon. Auk, 51:306-327.

McCabe, R. A., and Deutsch, H. F. 1952. The relationships of certain b1rds as indicated by thelr egs white protelns.
Auk, 69:1-18. 
Nice, M. M. 1941. The role of territory in bird life. Amer. M1dl. Nat., 26:441-487.

Petrunkevitch, A. 1926. The value of instinct as a taxonomic character in spiders. B1ol. Bull., 50:427-432.

Potter, J. H. 1949. Dominance relations between different breeds of domestic hens. Phys101. Zool., 22:261-280.

R1ddle, O., and Bates, R. W. 1939. Preparation, assay and actions of lactogenic hormone. Chap. XX in Sex and internal secretion (2nd ed.) edited by E. Alion (pp. 1088-1120). Baltimore: Williams and W1lkins.

Schjelderup-Ebbe, T. 1913. Honsenes Stemme: Bidrag t1l Hønsenes ksykologi. Naturen, 37:262-276. (Translated by H. H. Strands-

, 1922. Belträge zur Social-psychologle des Haushuhns. Zeltschr. P. Psychol., 88:225-252.

, 1935. Soc1al behavior in b1rds. Chap. XX in Handbook of social psychology, edited by C. Murchison (pp. 947-972). Worcester: Clark University Press.

Scott, J. P. 1950. The social behavior of dogs and wolves: an 1llustration of socloblological systemat1cs. Ann. N. Y. Acad. Sc1., 51(6):1009-1021.

Scott, J. W. 1941. Sexual selection in the sage grouse. Anat. Rec., Suppl., 81:55. 498.'

1942. Mating behavior of the sage grouse. Auk, 59:477-

1950. A study of the phylogenetic or comparative behavior of three specles of grouse. Ann. N. Y. Acad. Sc1., $51(6): 1062-1073$.

Snedecor, G. W. 1946. Statistical methods. Ames, Iowa: Iowa State College Press. Tegetmeler, W. B. 1873. The poultry book. London: George
Routledge and Sons.

Thorpe, W. H. 1951. The definition of some terms used in animal behaviour studies. Bull. Animal Behaviour, 9:1-7.

Tordoff, H. B. 1954. Soc1al organization and behavior in a flock of captive, non-breeding red crossbills. Condor, 56 
Wheeler, W. M. 1923. Soc1al l1fe among the 1nsects. New York: Harcourt, Brace and Co.

Whitman, C. 0. 1898. An1mal behavior. 16th Lecture of the Marine Blological Laboratory, Woods Hole, Mass. (pp. 285338).

257:1-161. Behavior in pigeons. Pub. Carnegie Inst. Wash., 


\section{BIOGRAPHICAL SKETCH}

Edw1n M. Banks was born March 21, 1926 in Ch1cago, Illino1s. He attended primary and secondary schools in Chicago, and entered the University of Chicago in February 1943. Following a three-year-perlod of service in the U.S. Navy, he returned to the University of Chlcago where he recelved the Bachelor of Sclence degree in Zoology in 1949. He continued study in Zoology and recelved the Master of Sclence degree in 1950. H1s research interests were in the fleld of animal behavior and his work was supervised by the late Dr. W. C. Allee. In 1951, he accepted the position of research assistant to Dr. W. C. Allee, then head of the Department of Blology of the Unlversity of Florida, and also continued work toward the Ph.D. degree in Blologg, conferred June 1955.

He is a member of PhI Sigma, the Society of S1gma X1, the Ecological Society of America, the American Association for the Advancement of Sclence, and the Soclety for the Study of Animal Behaviour. 
This dissertation was prepared under the direction of the chairman of the candidate's supervisory committee and has been approved by all members of the committee. It was submitted to the Dean of the College of Arts and Sciences and to the Graduate Council and was approved as partial fulfillment of the requirements for the degree of Doctor of Philosophy.

June 6, 1955

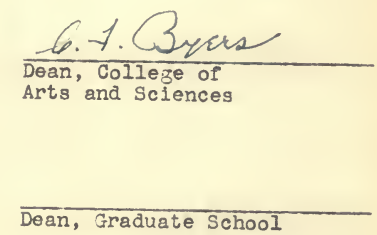

SUPERVISORY COMMITTEE:

Puffin tones for W.C. Allee (Accuse)

Quod Mother

ra mas H. Gregg

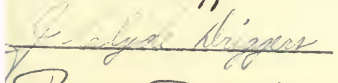

